\title{
Women and Constitution-Making in Post-Communist Romania
}

\author{
ELENA BRODEALĂ AND SILVIA ŞUTEU
}

\subsection{Introduction}

The role of women in constitution-making in Central and Eastern Europe (CEE) is an under-researched topic, as is the topic of women's role in the transition of the region to democracy. ${ }^{1}$ Literature regarding women's role in organisations involved in the collapse of communism such as the Solidarity Movement in Poland, or on women dissidents in Romania, does exist. ${ }^{2}$ However, very little attention, if any, has been

\footnotetext{
* We want to thank to the editors of this book for all their useful comments and their patience. We would also like to express our gratitude to those who gave us feedback and new ideas for improving this chapter, and in particular to Cornelia Weiss, who read and provided valuable suggestions on one of our first drafts; to Stefano Osella, Théo Fournier, Gábor Halmai and to the other participants at the presentation of this chapter at the European University Institute in Florence, Italy on 12 March 2018; to Bradley Gorski, Smoki Musaraj, Filip Erdeljac and Elidor Mëhilli, who commented on our paper at the panel on 'Post-Communist Transition and Transformation' at the Sortheastern Slavic, East European and Eurasian Studies Conference that took place at New York University's Jordan Centre for the Advanced Study of Russia on 7 April 2018; and to the participants to the panel on 'Women in Law and Society' at the Annual Meeting on Law and Society that took place in Toronto, Canada on 7-10 June 2018. Any errors are our own.

1 There are, of course, exceptions. See, for example, N. Funk and M. Mueller (eds.), Gender Politics and Post-Communism: Reflections from Eastern Europe and the former Soviet Union (New York: Routledge, 1993); J. S. Jaquette and S. L. Wolchik (eds.), Women and Democracy: Latin America and Central and Eastern Europe (Baltimore, MD: Johns Hopkins University Press, 1998); and G. Waylen, Engendering Transitions: Women's Mobilization, Institutions, and Gender Outcomes (Oxford University Press, 2007).

2 On Polish women's resistance under communism, see A. Reading, Polish Women, Solidarity and Feminism (Basingstoke: MacMillan, 1992); K. S. Long, We All Fought for Freedom: Women in Poland's Solidarity Movement (Boulder, CO: Westview Press, 1996); P. Kenney, 'The gender of resistance in communist Poland', The American Historical Review 104(2) (1999), pp. 399-425; and S. Penn, Solidarity's Secret: The Women Who Defeated Communism in Poland (Ann Arbor: University of Michigan Press, 2006). On Romanian dissidents, see G. Cormos, 'Romanian women under political repression during the communist era', Scientific Journal of Humanistic Studies, (3) (2010), pp. 18-28;
} 
given to women's involvement in constitution-making or constitutional litigation. This lack of attention reflects, to a certain extent, the dearth of constitutional scholarship on the region more generally. ${ }^{3}$ Very little is known about women as actors in constitution-making in CEE, and there is no serious gender analysis of the fundamental laws adopted in the region post-1989.

This chapter begins to fill this gap in the literature by setting out the contours of women's involvement in Romania's constitution-making process after the fall of communism. It does so by looking at the most important moments in Romania's post-1989 constitutional path and evaluating the extent to which women participated as actors in the process of constitution-making or had their interests included in the debates around the Romanian Constitution (RC). ${ }^{4}$ The chapter therefore provides an initial but much-needed account of the Constitution's foundations and evolution from a gender-sensitive perspective and should be seen as part of a broader research agenda forged around a gender analysis of Romanian constitutionalism. ${ }^{5}$

Resorting to the model proposed by other scholars, ${ }^{6}$ we can trace five key constitutional moments, or opportunities for constitutional change, since the fall of Communism. While not neatly self-contained, the

C. Petrescu, 'A genderless protest: Women confronting Romanian communism', Annals of the University of Bucharest 16(2) (2014), pp. 79-101; L. Stan, 'Women as anti-communist dissidents and secret police collaborators' in F. C. Andreescu and M. J. Shapiro (eds.), Genre and the (Post)Communist Woman: Analyzing Transformations of the Central and Eastern European Female Ideal (Abingdon, Oxon and New York: Routledge, 2014), pp. 80-97.

3 There are, of course, exceptions, although the most prominent comparative studies of the region also tend to mention the Romanian case just in passing. See, e.g., W. Sadurski, Rights Before Courts: A Study of Constitutional Courts in Postcommunist States of Central and Eastern Europe, 2nd edn (Dordrecht, Netherlands: Springer, 2014) and W. Sadurski et al., Rethinking the Rule of Law after Communism (Budapest and New York: Central European University Press, 2005).

${ }^{4}$ The 1991 Constitution, published in the Official Gazette no. 233 of 21 November 1991, republished with amendments in the Official Gazette no. 767 of 31 October 2003 (Constitutia din 1991, publicata in Monitorul Oficial nr. 233 din 21 noiembrie 1991, republicata cu modificari in Monitorul Oficial nr. 767 din 31 octombrie 2003).

${ }^{5}$ One of us works precisely on pushing forward this research agenda. See, e.g., E. Brodeala, 'The changing status of women as others in the Romanian constitution', Vienna Journal on International Constitutional Law 11(4) (2017), pp. 541-564.

${ }^{6}$ See, e.g., P. Blokker, 'Constitution-making in Romania: From reiterative crises to constitutional moment?', Romanian Journal of Comparative Law 3(2) (2013), 187-204; P. Blokker, 'The Romanian constitution and civic engagement', Vienna Journal on International Constitutional Law 11(3) (2017), pp. 437-455. 
metaphor of the constitutional moment does serve to delineate the turning points during which different groups could have pursued their interests in terms of establishing a new constitutional order or making the constitution more responsive to their demands. ${ }^{7}$ The five constitutional moments we identify are: the first constitutional moment starting in December 1989, immediately after the fall of communism, when the boundaries of power were being renegotiated; the second revolving around the process of writing and adopting the current Constitution between May 1990 and December 1991; the third incorporating the 2003 revision pursued in preparation for European Union (EU) and North Atlantic Treaty Organization (NATO) accession; ${ }^{8}$ the fourth, which included an unsuccessful attempt to revise the Constitution that started in 2013 and aimed at addressing the causes of some previous constitutional crises; and the last moment starting in 2015 and revolving around a citizens' initiative to review the Constitution and define family as the marriage between a man and a woman. We find that none of these moments explicitly pursued a gender-emancipatory agenda, nor did they see a critical mass of women, let alone feminists, rise up as key actors in the process of constitution-making or reform. However, the more recent constitutional moments do include a turn to popular participation and civil society which, given that women are better represented in the latter, has created some space for women's issues to be debated. Developments post-2015 may yet galvanise activists to engage more deeply with policymaking and to learn to articulate their demands in constitutional terms.

In telling the story of women and constitution-making in postcommunist Romania, we proceed in two steps. In Part 2, we provide a brief history of the development of women's rights in Romania so as to contextualise the constitutional debates that took place after 1989. We also provide some background on the state of, or rather lack of, a feminist

${ }^{7}$ In this sense, we only loosely follow Ackerman's notion of 'constitutional moments'. See B. Ackerman, We the People: Foundations (Cambridge, MA: Harvard University Press, 1991). We do acknowledge that, as Wojciech Sadurski has put it, the metaphor of 'constitutional moments' is not necessarily appropriate for the Central and Eastern European context, as 'We the People' did not have a voice in the processes of constitution-drafting of the region. W. Sadurski, 'Conclusions: On the relevance of institutions and the centrality of constitutions in post-communist transitions' in J. Zielonka (ed.), Democratic Consolidation in Eastern Europe, vol. 1: Institutional Engineering (New York: Oxford University Press, 2001), pp. 470-472. We nonetheless find the concept of 'constitutional moment' useful to organise the events we follow in this chapter and we use it rather in the sense of a constitution-making period/opportunity.

${ }^{8}$ Romania became a NATO member state in 2004 and an EU member state in 2007. 
movement in pre-1989 Romania and its fledgling beginnings until very recently. In Part 3, we discuss the five constitutional moments identified. These moments are not exhaustive, but they are the most important turning points in the period we examine. ${ }^{9}$ In analysing each of these moments, we seek to identify the general setting of the constitutional debates, the presence of women and their opportunities to engage with constitution-making, their eventual influence on the content of the Constitution and the way women's issues were framed and discussed during the constitution-making debates. Our conclusion aims to sum up the challenges and opportunities for engendering constitution-making in Romania thus far and points towards future axes of research.

\subsection{Context}

\subsubsection{Brief History of Women's Rights in Pre-1989 Romania}

Romania became a state in 1859 through the union of the historical provinces of Wallachia and Moldavia. In 1918, Transylvania, previously part of the Austro-Hungarian Empire, became part of this union. Certain territories, including a part of Moldavia, were lost in World War II, and the borders of Romania stand as we know them today since this moment. During Romania's monarchic times (1866-1947), three constitutions were adopted: in 1866, in 1923 and in 1938. Although progressive for their time, none of the three constitutions granted women full equal rights. They all excluded women from the succession to the throne and from enjoying full political rights. Until the 1923 Constitution was adopted, women were also denied equal civil rights with men. In Article 6, the 1923 Constitution required women's civil rights to be established 'based on the full equality of the two sexes'. Moreover, in Article 108, the 1923 Constitution gave women the right to be elected in county and local councils. Yet the regulation of political rights was subject to a special law that granted the right to vote and to be elected in county and local councils only to some categories of women (those who had a certain level of education, those who worked as public servants, who were war widows or who received war distinctions and women who led cultural

9 By this we mean simply to acknowledge that there have been other attempts at constitutional revision, though they were neither as comprehensive as the ones we discuss, nor were they successful. See, e.g., B. Dima, 'The commission for a new constitution - A civil society prospective on the process of constitutional revision', Romanian Journal of Comparative Law 2(1) (2011), pp. 151-172. 
societies or charities). ${ }^{10}$ The 1938 Constitution extended these political rights and gave women the right to be elected to the Senate. ${ }^{11}$ In 1939, the first woman Senator was elected. ${ }^{12}$ However, once again the 1938 Constitution gave women the right to vote only if they fulfilled certain preconditions; for example, if they worked in agriculture, did remunerated manual work, worked in the field of commerce or industry or if they had an intellectual occupation. ${ }^{13}$ It was only in 1946, when Romania had its first communist government headed by Petru Groza, that women received full and equal suffrage. ${ }^{14}$ However, given that no free elections took place until May 1990, it is fair to say that women's political rights in Romania have a very short history.

The communist regime and the transition of Romania to a Socialist Republic brought with them the full constitutional protection of women's rights, at least formally. ${ }^{15}$ Three constitutions were adopted during communism, two during the rule of Gheorghe Gheorghiu Dej (1948-1965) and another one after Nicolae Ceausescu came to power (1965-1989). The 1948 Constitution granted women full political rights, equality before the law and equality in all social domains. The 1952 Constitution added guarantees of women's rights with regard to employment and the right to assembly in women's organisations. Further, the 1965 Constitution introduced the protection of women workers and

10 See Article 375 of Law 167/1929. For an overview over the struggle to achieve women's suffrage in Romania see R. Cheschebec, 'Feminist Ideologies and Activism in Romania (Approx. 1890s-1940s): Nationalism and Internationalism in Romanian Projects for Women's Emancipation', unpublished $\mathrm{PhD}$ thesis, Central European University, Budapest, Hungary, History Department 2005/2.

11 See Articles 61 and 63 of the 1938 Constitution.

${ }^{12}$ Her name was Maria M. Pop. See also Cheschebec, 'Feminist Ideologies and Activism in Romania (Approx. 1890s-1940s)', pp. 390-397.

${ }^{13}$ See Articles 61 and 62 of the 1938 Constitution.

14 A. Baciu, The Role of the 1923 Constitution in Consolidating National Unity. The Evolution of the Constitutional Matter in Interwar Romania (Rolul Constitutiei din 1923 in Consolidarea Unitatiii Nationale. Evolutia Problemei Constitutionale in Romania Interbelica) (Bucuresti: Editura Stiintifica si Enciclopedica, 1988), p. 202; L. M. Jinga, Gender and Representation in Communist Romania: 1944-1989 (Gen si Reprezentare in Romania Comunista: 1944-1989) (Iasi: Polirom, 2015), p. 208; For more on women's suffrage in Romania, see R. Cheschebec, 'The Achievement of Female Suffrage in Romania' in B. Rodriguez-Ruiz and R. Rubio-Marin (eds.), The Struggle for Female Suffrage in Europe: Voting to Become Citizens (Leiden and Boston: Brill, 2012), pp. 357-372.

15 The qualification is due to the well-known discrepancy between the far-reaching individual protections afforded by communist constitutions and the reality of their implementation, which was often lacking. See, e.g., J. -E. Lane, Constitutions and Political Theory (Manchester University Press, 1996), p. 118. 
included the President of the Women's Council (the women's organisation of the Communist Party) in the Council of Ministers (the Government of those times).

As part of its plans for social engineering, the communist regime moved a significant part of the population from the countryside to the cities. ${ }^{16}$ The regime also enforced different policies and used its propaganda machinery to push women into paid work outside the home. However, many jobs remained closed to women. ${ }^{17}$ The communists also aimed to promote women in politics. For example, in 1948 Romania had the first woman Minister of Foreign Affairs in the modern world ${ }^{18}$ and, after the coming to power of Ceausescu, his wife Elena began playing an important role in Romanian politics and in the public sphere more broadly. ${ }^{19}$ At the same time, in the 1970 s, measures to increase women's political participation were also taken. ${ }^{20}$ Scholars of communist Eastern Europe generally describe these as 'gender quotas', although there are no serious studies to explain the design and exact functioning of these 'quotas. ${ }^{21}$ Such 'quotas', better described as affirmative action measures,

16 See P. Ronnas, 'Urbanization in Romania. A Geography of Social and Economic Change Since Independence', unpublished PhD thesis, Stockholm School of Economics, 1984.

17 See Jinga, Gender and Representation in Communist Romania, pp. 242-245, 331-357.

${ }^{18}$ Her name was Ana Pauker. R. Levy, Ana Pauker: The Rise and Fall of a Jewish Communist (Berkeley: University of California Press, 2001), p. 70.

19 For an overview of the role of Elena Ceausescu in the politics of the Communist Party, see M. E. Fischer, 'Women in Romanian politics: Elena Ceausescu, pronatalism, and the promotion of women' in S. L. Wolchik and A. G. Meyer (eds.), Women, State, and Party in Eastern Europe (Durham, NC: Duke University Press, 1985), pp. 121-137; C. L. Olteanu, 'The cult of Elena Ceausescu in the 1980s (Cultul Elenei Ceausescu in anii '80)' in A. Ciupala (ed.), About Women and Their History in Romania (Despre Femei si Istoria lor in Romania) (Editura Universitatii din Bucuresti, 2004), pp. 158-179; J. Massino, 'Women's anonymity in the aesthetics of Ceausescu's Romania (Anonimatul femeii in estetica Romaniei ceausiste)' in A. Ciupala (ed.), About Women and Their History in Romania (Despre Femei si Istoria lor in Romania), pp. 151-156; V. Vese, 'The condition of women in Romania during the communist period' in A. Katherine Isaacs (ed.), Political Systems and Definitions of Gender Roles (Edizioni Plus - Universita di Pisa, 2001), pp. 269-272; C. Lovatt, 'The legacy of Elena Ceaușescu', Central Europe Review 1 (3), 12 July 1999, www.ce-review.org/99/3/women_lovatt3.html.

${ }^{20}$ Fischer, 'Women in Romanian politics', pp. 125-129. See also Jinga, Gender and Representation in Communist Romania, pp. 217-221.

${ }^{21}$ D. Dahlerup and M. A. Gaber, 'The legitimacy and effectiveness of gender quotas in politics in CE Europe', Teorija in Praksa 54(2) (2017), p. 308; For more on women's political representation in Eastern Europe before and after the fall of communism, see M. Rueschemeyer (ed.), Women in the Politics of Postcommunist Eastern Europe (Armonk, NY: M. E. Sharpe, 1998); M. Janova and M. Sineau, 'Women's participation in political power in Europe', Women's Studies International Forum 15(1) (1992), pp. 115-128. 
were not enforced through legislation. This was not necessary given that Eastern European countries at that time had one-party systems and the Communist Party was in charge of both making the rules and enforcing them. These measures are instead best described as general party guidelines that were carefully observed due to the authoritarian character of the discipline within the Communist Party. ${ }^{22}$ In the case of Romania, scholars agree that the representation of women of around 30 per cent in the last two communist parliaments elected in 1980 and in 1985 was connected to Ceausescu's objective of increasing the presence of women in politics. ${ }^{23}$ Still, in spite of the relatively high representation of women in the communist parliaments, women were strongly underrepresented in the ruling bodies of the Communist Party, the place where power actually resided. ${ }^{24}$ Thus, the well-known 'Putman's Law', according to which the more important a position, the fewer women are likely to occupy it, ${ }^{25}$ is also applicable to the case of communist Romania. ${ }^{26}$

The figure of Elena Ceausescu deserves separate discussion. Unlike first ladies in the West, Elena Ceausescu was portrayed by the propaganda machinery of the regime as a political activist, an 'academician, doctor, engineer' and as a devoted wife and mother of three. ${ }^{27}$ Although the presence of women in communist politics was rather a matter of tokenism and of demonstrating the theoretical commitments of the communist regime to equality and democracy, ${ }^{28}$ Elena Ceausescu managed to reach the highest positions in the Communist Party and was generally perceived as ruling the country together with her husband. ${ }^{29}$ Due to her role, Jill Massino has described communist Romania as

22 See Jinga, Gender and Representation in Communist Romania, pp. 218-220.

${ }^{23}$ See, e.g., Fischer, 'Women in Romanian politics', pp. 132-133.

24 This is true more generally for the CEE countries during communism. See Janova and Sineau, 'Women's participation in political power in Europe', pp. 117, 122.

25 R. D. Putnam, The Comparative Study of Political Elites (Englewood Cliffs, NJ: PrenticeHall, 1976), pp. 33-37.

${ }^{26}$ See Fischer, 'Women in Romanian politics', p. 127.

${ }^{27}$ Massino, 'Women's anonymity in the aesthetics of Ceausescu's Romania', p. 151.

${ }^{28}$ Fischer, 'Women in Romanian politics', p. 131.

${ }^{29}$ It is not a coincidence that they were executed together on 25 December 1989, shortly after the outbreak of the Romanian Revolution. Elena Ceausescu also arguably saw herself as the 'mother of the nation'. A famous phrase that Elena shouted to the soldiers in charge of her execution was: 'Think, children, how for twenty years I was like a mother to you. Don't forget all I have done for you'. This phrase appears on the recording of her execution. Translation from T. Gallagher, Modern Romania: The End of Communism, the Failure of Democratic Reform, and the Theft of a Nation (New York University Press, 2008), pp. 72-73. 
unique when it came to the representation of women in politics. ${ }^{30}$ While political leadership in other dictatorships was seen as a trait of masculinity, to be exercised by strong male leaders, in Romania leadership was constructed around the Ceausescus in the spirit of Marxist ideals of sex equality. ${ }^{31}$ Moreover, constructing the persona of Elena Ceausescu went beyond the stereotypical image of the wife gaining political prestige because of her husband. To underline that only competent individuals could hold office in communist Romania, the regime promoted Elena Ceausescu as a scientist. ${ }^{32}$ Elena Ceausescu became the head of the National Institute for Chemical Research, received a $\mathrm{PhD}$ in Chemistry and later on was admitted as a member of the Romanian Academy of Sciences. She was also admitted as member of Western institutions such as the New York Academy of Sciences and the Royal Institute of Chemistry from London. ${ }^{33}$ Nonetheless, it is common knowledge for the Romanian public and historians that her research papers were either plagiarised or were written by other scholars who were duly compensated for helping the first lady to advance her image as a 'symbol of Romanian modernization'. ${ }^{34}$ In the last years of communism, a veritable cult of personality of the first lady emerged and the political position of Elena Ceausescu was strengthened. ${ }^{35}$ She was supposed to be a model for other working women in Romania. Using Elena Ceausescu as a model ultimately backfired after 1989, leading to a rejection of women from politics and a rejection of involvement in politics by women themselves.

Furthermore, although not her doing and although women from the Communist Party seem to have disagreed with the adoption of repressive pronatalist measures by the regime, ${ }^{36}$ the image of Elena Ceausescu is often associated with these measures. ${ }^{37}$ These were drastic and unduly restricted women's autonomy, equality and right to health. They encompassed one of the most restrictive anti-abortion laws in the history of Europe; forced gynecological check-ups disguised as mandatory regular

30 Massino, 'Women's anonymity in the aesthetics of Ceausescu's Romania', p. 151.

${ }^{31}$ Massino gives the example of male dictators such as Lenin, Stalin, Hitler or Mussolini. Ibid.

${ }^{32}$ Olteanu, 'The cult of Elena Ceausescu in the 1980s', p. 163.

33 Ibid., p. 164.

34 Ibid., p. 169.

${ }^{35}$ Ibid., pp. 170-178.

${ }^{36}$ See R. M. Popa, "We opposed it": The National Council of Women and the ban on abortion in Romania', Aspasia 10(1) (2016), pp. 152-160.

37 Fischer, 'Women in Romanian politics', p. 124. 
medical examinations at the workplace; limited availability of contraception; taxes on childless citizens older than twenty-five and the awarding of 'heroine mother' medals or similar medals to women who had more than five children. ${ }^{38}$ At the same time, the care-taking infrastructure built by the communists was insufficient for the increasing number of newborns; no 'extended maternity leaves' were given in communist Romania, unlike other countries in the region such as in Hungary or Czechoslovakia, ${ }^{39}$ and there were no incentives for men to share the burdens of the household and childcare. In this way, Romanian women had to perform double the work, in the public sphere of socialist production and in the private sphere of human reproduction. ${ }^{40}$ This had dramatic consequences. It is estimated that during the twenty-three years of Ceausescu's pronatalist policies around 10,000 women died because of illegal abortions, 2,000 women ended up in prison, and many others faced significant health problems. This legacy had a great impact on the status of women after 1989 and on their involvement in the public sphere. It also resulted in the public associating gender equality policies with a malfunctioning communist regime and the image of Elena Ceausescu.

\subsubsection{Feminism and the Women's Movement in Communist and Post-Communist Romania}

During the 1990s, the legacy of communism manifested through an overall lack of gender awareness and of a grassroots women's movement or feminist advocates. ${ }^{41}$ The communist regimes in CEE generally did

${ }^{38}$ For on overview of the pronatalist policies of the Ceausescu regime, see G. Kligman, The Politics of Duplicity: Controlling Reproduction in Ceausescu's Romania (Berkeley: University of California Press, 1998).

39 In spite of Ceausescu's pronatalist policies, women in Romania benefited only from a 112-workday maternity leave. Unlike in other CEE countries, no parental leave (or 'extended maternity leave' as Saxonberg calls it since it was opened only to women to be taken at the end of maternity leave) existed in Romania. S. Saxonberg, Gendering Family Policies in Post-Communist Europe: A Historical-Institutional Analysis (Basingstoke: Palgrave Macmillan, 2014), p. 53; See also Kligman, The Politics of Duplicity, pp. $71-86$.

40 W. Moskoff, 'The problem of the "double burden" in Romania', International Journal of Comparative Sociology 23(1-2) (1982), pp. 79-88; For a more general overview of the problem of double burden during Communism in CEE see C. Corrin (ed.), Superwomen and the Double Burden: Women's Experience of Change in Central and Eastern Europe and the Former Soviet Union (London: Scarlet Press, 1992).

${ }^{41}$ D. P. Harsanyi, 'Romania's women', Journal of Women's History 5(3) (1994), pp. 50-52. 
not welcome 'competing ideologies' such as feminism, which was seen as 'bourgeois' and therefore incompatible with communism. ${ }^{42}$ Moreover, since citizens could not express different opinions or generally create alternative organisations to the Communist Party, no grassroots women's movement could develop in communist Romania as it did in the West in the 1960s and 1970s. The major writings of second-wave feminists in the West appear not to have been accessible in Romania until the fall of communism. ${ }^{43}$ At the same time, starting from 1970s, the study of sociology (which would normally encompass gender studies) was also generally excluded and/or marginalised in Romanian universities and research institutions, as its results did not resonate with the political dogma of the regime. ${ }^{44}$ Therefore, as Mihaela Miroiu - one of the most emblematic figures of Romanian feminism in the post-communist period - has noted, after 1989, 'feminism had to be reinvented and rediscovered ... the same way in which liberalism and democratic socialism had to be'. ${ }^{45}$

The first women's organisations that appeared after 1989 were the so-called Phoenix organisations, as they were allegedly created from the ashes of the National Council of Women of the Communist Party and did not truly embrace the principles of liberal democracy. In a list created by the United Nations Development Programme (UNDP) in 1994,

${ }^{42}$ M. Miroiu, 'On women, feminism and democracy' in L. Stan and D. Vancea (eds.), PostCommunist Romania at Twenty-Five: Linking Past, Present, and Future (Lanham, MD: Lexington Books, 2015), p. 89.

${ }^{43}$ K. Ghodsee, 'On feminism, philosophy and politics in post-communist Romania: An interview with Mihaela Miroiu (Bucharest, 17 May 2010)', Women's Studies International Forum 34(4) (2011), p. 303. Just to give one example, Simone de Beauvoir was known in Communist Romania only as a writer and not as a philosopher and her book 'The Second Sex' was not translated into Romanian until 1998. E. Leveél, 'The second sex after sixty years. A Romanian perspective (Al doilea sex după șaizeci de ani. O perspectivă românească)', Revista Verso, 73 (2009), pp. 13-14, cited in E. Leveél, 'Simone de Beauvoir and Romania: A distant gaze (circa 1965-1977)', Colloquia. Journal of Central European History 19 (2012), note 36.

${ }^{44}$ See C. Zamfir and I. Filipescu (eds.), Romanian Sociology: 1900-2010. A Social History (Sociologia Romaneasca: 1900-2010. O Istorie Sociala) (Cluj-Napoca: Editura Scoala Ardeleana, 2015), pp. 95-99; See also C. Cotoi, 'Jottings on the history of Romanian sociology', Studia Universitatis Babes-Bolyai-Sociologia 56(1) (2011), pp. 135-149; Z. Rostas, 'The second marginalisation of the Bucharest sociological school', ACUM 5 (1) (2011), pp. 69-80; S. Bosomitu, 'In the age of "misery". The Romanian sociology during the communist regime (1948-1977) [I]', Cooperativa Gusti, 2 December 2013, www.cooperativag.ro/age-misery-romanian-sociology-communist-regime-1948-1977/.

45 Miroiu, 'On women, feminism and democracy', p. 94. 
thirty-eight women's organisations were listed. ${ }^{46}$ Yet just one, AnA Society for Feminist Analyses, was listed as a feminist organisation. ${ }^{47}$ Furthermore, disappointed by the fact that after 1989, political power was taken mainly by people with ties to the former Communist Party and believing that politics was a 'dirty business', women's organisations preferred to stay away from trying to influence the institutions of the state. ${ }^{48}$ The fact that we could not document the involvement of any women's organisation in the first two constitutional moments that took place between 1989 and 1991, right after the fall of communism, is not surprising. Not only were women's organisations at that time in an incipient phase, but the first constitutional debates after the fall of communism were conducted without input from civil society more broadly. ${ }^{49}$

The transition period saw the growth in number and diversity of women's NGOs in Romania, although their involvement in public life, and especially in political life, remained scarce. As Grunberg explains in her study regarding women's NGOs in Romania, by 2000 most NGOs were focusing on providing everyday services for women, or more rarely on community building, and were not 'institutionally oriented', that is, interested in influencing 'government policies, election processes, and civil and political behavior'. ${ }^{50}$ Moreover, despite the opportunities afforded by the process of European accession in the 2000s, women's rights NGOs in Romania did not come out of the accession process better able to influence public policy and law-making. They are instead said to have developed a type of 'room-service' feminism, in the sense of accepting the imposition of gender-sensitive legislation by external actors

${ }^{46}$ A. Molocea, 'Reconstructing Romanian feminism within women's movement (1990-2000) [(Re)Constructia Feminismului Romanesc in Cadrul Miscarii de Femei (1990-2000)]' in M. Miroiu (ed.), Environmental and Feminist Movements in Romania (1990-2014) [Miscari Feministe si Ecologiste in Romania (1990-2014)] (Iasi: Polirom, 2015), p. 23.

47 Ibid., p. 29.

${ }^{48}$ L. Grunberg, 'Women's NGOs in Romania' in S. Gal and G. Kligman (eds.), Reproducing Gender: Politics, Publics, and Everyday Life after Socialism (Princeton University Press, 2000), p. 310.

49 D. I. Pietraru, 'The Romanian Constitution of 1991: The 'Stolen' Constitution', unpublished PhD thesis, New School of Social Research, New York, United States of America (1996), p. 327.

50 Grunberg, 'Women's NGOs in Romania', pp. 312, 320-21. 
rather than being active actors in demanding and negotiating the content of such legislation. ${ }^{51}$

It was only in 2010 that women's NGOs started publicly challenging governmental policies. This was when they organised a protest against cuts to allowances for mothers, which had been included in the government's austerity plans. ${ }^{52}$ Furthermore, in 2012, feminist activists joined a broader anti-austerity popular mobilisation in Romania. ${ }^{53}$ In 2013, several organisations working on women's rights, together with other interested groups, openly criticised the lack of transparency of the proceedings of the Commission to Review the Constitution, which had excluded them from giving input on the work of the Commission. ${ }^{54}$ Such activities mark the beginning of a women's movement more involved in the debates over public policies and legislation.

One of the reasons for this development may well be a new generation of young feminists more active and eager to engage with politics than their predecessors. In the first decade after 1989, feminist activities had generally revolved around a small group of female intellectuals working in different universities in Romania. Reacting to the communist past that denied citizens' autonomy, they generally embraced the liberal stream of the second-wave feminism. Moreover, as they could not identify themselves with the agenda of any political party, they preferred to keep some distance from the political sphere and dedicated themselves mainly to feminist intellectual and civic activities. ${ }^{55}$ It was only after 2000, and especially after Romania's EU accession, that third-wave feminism emerged in Romania. ${ }^{56}$ Feminists concerned about the intersection of different axes of inequality such as class, ethnicity or sexuality have

51 The term 'room-service feminism' was coined by Mihaela Miroiu. M. Miroiu, The Road to Autonomy. Political Feminist Theories (Drumul catre Autonomie. Teorii Politice Feministe) (Iasi: Polirom, 2004), pp. 256-260; See also I. Borza, 'A lacking legitimacy in the transposition of the EU's equal opportunity directives: The case of Romania', Women's Studies International Forum 33(1) (2010), pp. 47-53.

52 Molocea, 'Reconstructing Romanian feminism', p. 41.

53 See A. Ana, 'The role of the feminist movement participation during the winter 2012 mobilisations in Romania', Europe-Asia Studies 69(9) (2017), pp. 1473-1498.

54 Open Letter: The Process of Constitutional Review Must Be Transparent! (Scrisoare Deschisă: Procesul de Revizuire a Constituției Trebuie sa Fie Transparent!), ECPI, 13 March 2013, on-line, www.ecpi.ro/scrisoare-deschisa-procesul-de-revizuire-a-constitutieitrebuie-sa-fie-transparent.

55 Miroiu, 'On women, feminism and democracy', pp. 94-96.

56 Ibid., pp. $98-100$. 
started being active in the Romanian public sphere. ${ }^{57}$ They were especially quick in reacting to the 2015 citizens' initiative meant to introduce a traditional definition of the family in the Constitution. Thus, one can claim that it took over a quarter of a century for a feminist movement to appear in post-communist Romania, and, as we show next, its flagbearers are still learning to respond to attacks on the constitutional front.

\subsection{Women and Romania's Post-Communist Constitutional Moments}

In this section, we analyse from a gender perspective Romania's five main constitutional moments. The first such constitutional moment we identify is December 1989, right after the outbreak of the Romanian Revolution and the change of political regime. As we explain in Section 2.3.1, this period was dominated by what was meant to be a provisional group, the National Salvation Front (Frontul Salvarii Nationale, FSN), which was supposed to exercise state power until democratic elections took place. The second moment came after the May 1990 elections, when the new parliament, doubling as constituent assembly, was to elaborate the new Constitution. The third constitutional moment we identify came in 2003 in the context of NATO and EU accession. The fourth moment we refer to covers the 2013-2014 attempt to revise the Constitution. While the constitutional reforms initiated then were ultimately not adopted, the fourth moment brought in a more participatory approach to the Romanian constitutional amendment process, in the form of public consultations meant to feed into the final revision. ${ }^{58}$ As will be seen, however, this did not automatically go hand in hand with significant gains for women's rights. Lastly, we discuss the recent debates around a citizens' initiative to review the Constitution that aimed to redefine family in the text of the Constitution as the marriage between a man and a woman. Specifically, we note the unprecedented nature of this moment and the opportunities that women gained to engage in the debates around amending the constitution, although the content of the proposed amendment itself is built on a sexist, conservative agenda of religious

${ }^{57}$ For an overview over women's movement in Romania after 2000 see I. Vlad, 'Developments within Romanian women's movement after 2000 (Dezvoltari in Miscarea de Femei dupa 2000)' in M. Miroiu (ed.), Environmental and Feminist Movements in Romania (1990-2014), pp. 89-187.

58 See Blokker, 'The Romanian constitution and civic engagement', pp. 150-153. 
inspiration. Each of these five moments has its specificity due to the historical context in which they took place and should be understood within that context. Thus, in what follows, we explain the socio-political background to each moment, the extent to which women had opportunities to (and actually did) participate in the constitution-making processes and the extent to which women's rights were discussed in relation to the Constitution.

\subsubsection{December 1989-May 1990. Reorganising the State after the Fall of Communism}

The Romanian Revolution started on December 16, 1989. On 22 December, after a failed attempt to address the people in the capital city, Bucharest, and condemn the beginning of the insurrection, Ceausescu and his wife were forced to flee. They were captured shortly after in Targoviste, a city not far from Bucharest, and were executed on Christmas Day, after a brief trial before an ad hoc military tribunal. On the same day as the Ceausescus fled, the FSN was established to manage state power until new elections could take place. To this day, there is no consensus among scholars on whether the fall of the Ceausescus was caused by a coup d'état (arranged by their opponents in the Communist Party) or by the popular Revolution. Therefore, there is no clear answer to the question of how the FSN was constituted. While the official narrative is that the FSN was spontaneously constituted on the night of 22 December 1989 'to establish democracy, liberty and the dignity of the Romanian people', ${ }^{59}$ as Siani-Davies points out, there are speculations that the FSN was formed six months before the outbreak of the Romanian Revolution. ${ }^{60}$ Be that as it may, the FSN was likely formed based on the informal networks of its members. Thus, the extent to which women were included in the FSN probably depended on whether they were part of these networks. As we explain in this section, although the FSN had some female members, the actual power was held by a small group of former communist activists, all men. ${ }^{61}$

59 Communique to the Country of the Front of National Salvation Council, published in the Official Gazette, Part I no.1 of 22 December 1989 (Comunicat catre Tara al Consiliului Frontului Salvarii Nationale, Publicat in Monitorul Oficial, Partea I no. 1 din 22 decembrie 1989).

60 P. Siani-Davies, The Romanian Revolution of December 1989 (Ithaca, NY: Cornell University Press, 2005), pp. 165-170.

${ }^{61}$ For exact names see Gallagher, Modern Romania, p. 73. 
On 26 December, the four-day-old FSN nominated a new provisional government headed by Petre Roman and a Council that had legislative powers. ${ }^{62}$ The Council was headed by Ion Iliescu, who would later be elected as the first president of post-communist Romania. Iliescu also acted as the interim president of Romania until elections took place. In this context, the FSN was the entity that initially had the power to establish a new constitutional order. The FSN had thirty-nine founding members. These consisted of anti-communist dissidents as well as former members of the communist nomenclature. Only five founding members of the FSN were women: Ana Blandiana, Doina Cornea, Cristina Ciontu, Eugenia Iorga and Magdalena Ionescu. The founding members of the FSN were also the members of the Council. Among the five women in the Council, Ana Blandiana and Doina Cornea, both well-known anti-communist dissidents, were to become emblematic figures of the Revolution - although they resigned from the FSN about a month after becoming members. According to Blandiana, she and Cornea were publicly announced as members of the FSN before they were themselves told about it, and it is not clear who added them onto the FSN list. ${ }^{63}$ Furthermore, since the interim president, Ion Iliescu, saw Blandiana, a widely read poet, as 'somebody very loved' ${ }^{64}$ by the people, he proposed her as one of the two potential vice-presidents of the Executive Office of the Council, the body that actually exercised power. ${ }^{65}$ As Blandiana realised that she, Cornea and others had only been included in the FSN as a sign of tokenism and not to truly contribute to the founding of democracy in Romania, she declined this role. ${ }^{66}$ Thus, the Executive Office of the Council ended up with no women members. ${ }^{67}$

62 Established by Decree no.2/1989.

63 'The first meeting of poet Ana Blandiana with Ion Iliescu, in December 1989. 'This is when I understood that people like Doina Cornea and me were there to be put in the window' (Prima intalnire a poetei Ana Blandiana cu Ion Iliescu, in decembrie 1989. 'Atunci am inteles ca oameni ca Doina Cornea si ca mine erau acolo sa fie pusi in vitrina')', Revolutions, 19 December 2014, www.revolutions.gandul.info/stiri/prima-intalnire-a-poetei-ana-blandi ana-cu-ion-iliescu-in-decembrie-1989-atunci-am-inteles-ca-oameni-ca-doina-cornea-si-camine-erau-acolo-sa-fie-pusi-in-vitrina-13732015; A. Blandiana, False Treatise of Manipulation (Fals Tratat de Manipulare) (Bucuresti: Humanitas, 2013), pp. 399-415.

${ }^{64}$ Blandiana, False Treatise, p. 412.

65 Ibid., p. 411; Siani-Davies, The Romanian Revolution of December 1989, p. 191. The Executive Office had a president, a prime vice president and two vice-presidents.

66 Blandiana, False Treatise, pp. 411-413; 'The first meeting of poet Ana Blandiana with Ion Iliescu, in December 1989'.

67 The president of the executive office was Ion Iliescu, the prime vice-president was Dumitru Mazilu; Then vice-presidents were Cazimir Ionescu and Karoly Kiraly; Secretary was Dan Martian and the members of the executive office were Bogdan Teodoriu, Vasile 
Whereas her reputation would have helped bolster the FSN's legitimacy and public trust, Ana Blandiana seems to have been offered the position of vice-president also for being a woman. In the transcript of the debate that took place during the first meeting of the FSN on 27 December 1989, when Iliescu brought up the nomination of two vice presidents, he specifically mentioned that among them he 'would propose a woman' ${ }^{68}$ In our opinion, the fact that the FSN leaders wanted to nominate a woman as the vice-president of the Executive Office should not be surprising - these leaders should have been accustomed to the informal rules of the Communist Party to promote token-women in public positions. ${ }^{69}$ Ana Blandiana has since explained that the FSN leaders had seriously insisted that she should accept the position. ${ }^{70}$ In the transcript of the FSN meeting, however, only a very short dialogue on the matter is recorded. Blandiana is recorded as refusing to be a tokenwoman in a high position, as was the norm during communist times. She

\footnotetext{
Neacsa, Silviu Brucan, Gheorghe Manole, Ion Caramitru and Nicolae Radu. T. StanescuStanciu, 'Introductive study. A new Central and South-East Europe and its new political structure: Constitutional corpus. Romania (Studiu introductiv. Noua Europa Centrala si de Sud-Est si noile sale structuri politice. Corpusuri constitutionale. Romania)' in T. Stanescu-Stanciu and F. Neacsu (eds.), The First Constitution of Post-1989 Romania. Documents (Prima Constitutie a Romaniei Postdecembriste. Documente), vol. I (Ploiesti: Karta-Graphic, 2011), p. 36. Gallagher also talks about a 'directing group' within FSN comprising eight men, all former members of the Romanian Communist Party: Ion Iliescu, Petre Roman, Silviu Brucan, Corneliu Manescu, General Victor Stanculescu, Alexandru Birladeanu and Dan Martian. Gallagher, Modern Romania, p. 73. When discussing about the leadership of FSN, Siani-Davis discusses only about men. See Siani-Davies, The Romanian Revolution of December 1989, pp. 195-199.

68 The Transcript of the Council of FSN from 27 December 1989 (Stenograma Sedintei CFSN din 27 Decembrie 1989), on file with the authors. The transcript was made public in February 1996 by Ion Iliescu, that time, the president of the country. NB: according to Ana Blandiana, the transcript that was made public was significantly cut and modified. One is left with the question of whether there were reasons for the transcript to be altered regarding the issue of women's political representation. Regardless of one's conclusion to that question, the interpretation of this source should be done with caution. Blandiana, False Treatise, p. 410.

69 During the same meeting, it was decided that the Council of FSN had to represent different categories. This resembles the way the Communist Parliament (Marea Adunare Nationala) was constituted. See the declarations of Ion Iliescu in 'The Transcript of the Council of FSN from 27 December 1989'. During this meeting, it was drafted Decree-Law no. 2/1989 regarding the Formation, the Organizing and the Functioning of the Council of FSN and of the Territorial Councils of FSN. Its preamble stated that the Council of FSN had to comprise representatives of 'all patriotic forces of the country, of all social categories, and all nationalities'.

${ }^{70}$ Blandiana talks about a half-hour discussion. See Blandiana, False Treatise, p. 411.
} 
has further explained that in her view she was not competent enough to hold such a position and that competency should be a precondition for women, same as for the rest of the population. She then pointed to the 'horror' of unqualified women promoted by the Communist Party and explained that she did not want to contribute to repeating the practice of nominating such women in public office for propaganda reasons. ${ }^{71}$ Blandiana later became an important civil society figure. In her memoirs, she has explained that the real reason behind her refusal to occupy a high position in the FSN was her concern about the moral compass of those who ruled it. ${ }^{72}$

The Council of the FSN comprised different committees. One of the committees was dedicated to constitutional affairs and was composed of six men. ${ }^{73}$ Regarding equality, there was just one committee dedicated to the issues of national minorities, but no committee referred to women's rights or to gender equality specifically and no committee was headed by a woman. ${ }^{74}$

Why women were under-represented within the structures of the FSN Council is difficult to pinpoint. On the one hand, it might have to do with a continuation of the communist past and its patriarchal order; ${ }^{75}$ on the other hand, it may have been precisely a rejection of this past and of its artificial gender equality measures. ${ }^{76}$ As explained in Section 2.2.1, the communist regime in Romania actively promoted women, including in the national parliament. Yet, as different scholars have observed, women were still under-represented in the Executive Office of the Communist Party and other bodies where power resided. ${ }^{77}$ In this sense, the lack of women in the revolutionary decision-making bodies can be seen as just a continuation of the patriarchal order of the previous regime.

Conversely, researchers also speak about a rejection of the previous regime manifested through a general disinclination towards women's

71 'The Transcript of the Council of FSN from 27 December 1989'.

${ }_{73}$ Blandiana, False Treatise, pp. 406-409.

73 E. Focseneanu, The Constitutional History of Romania (1859-2003) [Istoria Constitutionala a Romaniei (1859-2003)], vol. III (self-published by E. Focseneanu, 2009), p. 258.

${ }^{74}$ I. Bucur, Year 1990: Parties, Ideologies and Political Mobilization (Anul 1990: Partide, Ideologii si Mobilizare Politica) (Bucuresti: IRRD, 2014), pp. 20-21.

75 On the problem of feminism during Communism, see M. Miroiu, 'Communism was a state patriarchy, not state feminism', Aspasia 1 (2007), pp. 197-201.

76 This is for example the case of gender quotas, which have been rejected in CEE countries since 1989 due to their association with the communist regime. See Dahlerup and Gaber, 'The legitimacy and effectiveness of gender quotas in politics in CE Europe', p. 308.

77 See Fischer, 'Women in Romanian politics', pp. 127-130. 
participation in politics. ${ }^{78}$ This reluctance can be attributed to the artificial measures taken to increase women's participation in the public sphere (as a token of the egalitarian ideology of the regime), but also to the association of women's involvement in national politics with the image of Elena Ceausescu. ${ }^{79}$ Gail Kligman, one of the most important scholars writing about gender relations in communist Romania, disagrees with the idea that the image of Elena Ceausescu influenced the political participation of women after 1989. In her 1990 article on the birth of civil society in Romania after the collapse of communism, Kligman stated that 'to assert, as some have, that ... [the lack of women's participation in political decision-making] is a reaction to Elena Ceausescu's former presence is to beg the issue, ${ }^{80}$ However, an examination of the political debates following 1989 shows that the hypothesis of the Elena Ceausescu syndrome, which associates women's presence in politics with the perceived 'malefic' influence of Elena Ceausescu on communist politics, cannot be easily dismissed. ${ }^{81}$ As we will discuss in Section 2.3.2, women's representation in the first parliament after 1989 - a parliament which also acted as a constituent assembly - decreased dramatically (to less than 5 per cent) as compared to the last two communist parliaments where the presence of women had ranged around 30 per cent; this was the most serious such decrease in the region. ${ }^{82}$ Therefore, the reason women were heavily underrepresented in Romanian politics after the fall of the Ceausescu regime seems more complex than either the existence of a patriarchal culture or the association of women in politics with a discredited communist regime.

${ }^{78}$ M. E. Fischer, 'From tradition and ideology to elections and competition: The changing status of women in Romanian politics' in M. Rueschemeyer (ed.), Women in the Politics of Postcommunist Eastern Europe, p. 182.

79 Ibid.

${ }^{80}$ G. Kligman, 'Reclaiming the public: A reflection on creating civil society in Romania', East European Politics and Societies 4(3) (1990), p. 425.

${ }^{81}$ Other scholars of women's political participation in Romania seem to endorse the hypothesis of the 'Elena Ceausescu syndrome'. See, e.g., C. Chiva, Gender, Institutions and Political Representation: Reproducing Male Dominance in Europe's New Democracies (London: Palgrave Macmillan, 2017), pp. 102, 108-109. For post-1989 political debates that invoke the communist past and the image of Elena Ceausescu in relation to women's political participation, see T. Mihai, 'The Political Representation of Romanian Women, in the Context of Europeanization (Reprezentarea Politica a Femeilor din Romania, in Contextul Europenizarii)', unpublished PhD thesis, Scoala Nationala de Studii Administrative si Politice (National School of Administrative and Political Studies), SNSPA, Bucharest, Romania, 2016, pp. 143-146;

82 See Janova and Sineau, 'Women's participation in political power in Europe', p. 117. 
The fact that several of the members of the FSN belonged to the former nomenklatura is significant. That those members were predominantly men perhaps confirms the marginal role women played in the Communist Party. Why members of the National Council of Women, the women's organisation of the Communist Party, ${ }^{83}$ or other women from the Communist Party were not on the list of the initial members of the FSN is worth further research. Such research should explain what the factors (or actors) were that hindered women's involvement in the FSN. For example, Liliana Pagu, a former opera singer, claims to have been the one to have dissolved the National Council of Women right after the outbreak of the Romanian Revolution. She also claims to have organised the Democratic Front of Women (a provisory post-revolutionary temporary entity). ${ }^{84}$ Pagu is often accused by Romanian feminist scholars and activists of having continued the undemocratic practices of the former Communist Party. ${ }^{85}$ Yet, since many of those who took power after 1989 were in any case associated with the former regime, why were she and other women, who arguably had an equal connection to the former Communist Party, left out? An answer to this question probably resides in the way the FSN was constituted (based on male-dominated informal networks). Nonetheless, further research is needed to fully explain why the women from the power structures of the former regime were missing from the FSN.

The most emblematic female figures of the 1989 Romanian Revolution who were also part of the FSN belonged to the category of anticommunist intellectual dissidents. They were the already-mentioned

${ }^{83}$ According to Popa, 'Consiliul National al Femeilor (the National Council of Women, CNF) was the longest-surviving women's organisation during the communist regime in Romania, from 1958 to 1989 '. Popa, 'We opposed it', pp. 152-153.

84 'Official Website of Women's Association of Romania (Asociatia Femeilor din Romania)', www.afr.ro/english/pagu.htm\#militantul. On this website it is noted that 'On December 28, 1989, through a TV appeal, ... Liliana Pagu had mobilised women in the country to destroy the old communist forms of the women movement and to unify their forces for a new historical period of Romania'. More research is needed to understand the role and composition of Pagu's Democratic Front of Women, the new entity that was meant to replace the National Council of Women.

85 Molocea, 'Reconstructing Romanian feminism', pp. 23-26; Miroiu, 'On women, feminism and democracy', p. 93; See also Grunberg, 'Women's NGOs in Romania', p. 318. A 2014 interview with Pagu starts by explaining that 'The Women's Association of Romania (AFR) [currently headed by Pagu] began as a mass movement constructed out of the ruins of the previous Communist-era women's organization', J. Feffer, 'Empowering women in Romania', John Feffer (blog), 31 July 2014, www.johnfeffer.com/ empowering-women-in-romania/. 
Doina Cornea, a university lecturer, and the poet Ana Blandiana. ${ }^{86}$ Cornea was known for her clandestine letters criticizing the regime that were sent to Radio Free Europe, which led to her house arrest and constant surveillance for several years prior to December 1989. Apart from advocating free speech, freedom of association and freedom to travel, she also advocated for the freedom of the banned Romanian Church United with Rome and the preservation of traditional life in Romanian villages. ${ }^{87}$ Blandiana was well known for her dissidence through poetry. She criticised both Ceausescu personally and his policies. Of all her poems, the work that is most representative of a women's rights perspective is probably her 1984 poem 'Children's Crusade' in which she openly speaks against Ceausescu's anti-abortion law. ${ }^{88}$ This poem is what gave birth to the belief that Ana Blandiana, and perhaps Doina Cornea, were behind Decree no. 1/1989 - adopted just one day after the execution of the Ceausescus - that decriminalised abortion in Romania. ${ }^{89}$ Nevertheless, in one of her interviews Ana Blandiana recalled not only that she and Doina Cornea were put on the FSN list without their knowledge (or their consent), but that they first met the FSN members on 27 December 1989. ${ }^{90}$ Since Decree no. 1 was adopted on

${ }^{86}$ Fischer, 'From tradition and ideology to elections and competition', 182.

87 D. Deletant, Ceausescu and the Securitate: Coercion and Dissent in Romania, 1965-1989 (London: Hurst \& Company, 1995), pp. 266-267; See also Kligman, 'Reclaiming the public', 399; D. Cornea, The Power of Fragility (Puterea Fragilitatii) (Bucuresti: Humanitas, 2006); D. Cornea, Journal: Last Notebooks (Jurnal: Ultimele Caiete) (Bucuresti: Fundatia Academia Civica, Centrul International de Studii asupra Comunismului, 2009).

88 The poem reads as follows:

\author{
'An entire people, \\ not yet born, \\ but condemned to birth \\ in columns before birth \\ foetus beside foetus, \\ an entire people \\ which does not see, does not hear, does not understand, \\ but moves forward. \\ Through writhing bodies of women, \\ Through the blood of mothers
}

unconsulted.' Translation from footnote 71 in Deletant, Ceausescu and the Securitate, p. 195.

89 The idea that Ana Blandiana and perhaps Doina Cornea were behind legalizing abortion after the outbreak of the Romanian Revolution is generally speculated by pro-life groups in Romania. Such information can be found on a simple web search.

90 'The First Meeting of Poet Ana Blandiana with Ion Iliescu, in December 1989'. 
26 December 1989, Blandiana and Cornea could not have been involved in its drafting. Thus, abortion seems to have been decriminalised at the initiative of the male-dominated group that formed the FSN.

The FSN was not a political party, but an organism meant to manage state power until political parties could be constituted and elections could take place. However, on 23 January 1990 its leaders decided to turn the FSN into a political party and run for elections. This meant that, not unlike during the communist regime, the FSN members would be the ones in charge of organising the elections, ensuring their integrity and running for office at the same time. Due to this controversial decision, the most principled members of the FSN resigned. These included Ana Blandiana and Doina Cornea, as well as several of the male membership.

As a response to the protests of the other political parties regarding the FSN becoming a political party, the Council of the FSN modified its composition so as to comprise half members of the newly constituted FSN political party and half members of the other political parties and entities. ${ }^{91}$ In this context, the first political split in post-communist Romania was represented by the FSN and anti-FSN forces. The Council also changed its name to the Provisional Council of National Union (Consiliul Provizoriu de Uniune Nationala, CPUN). When it started functioning, the CPUN ended up having 259 members: 112 were part of the FSN, 102 came from thirty-four political parties (three from each party), thirty-nine came from thirteen organisations of national minorities, three members came from the organisation of former political detainees and three members were part of a trade union. ${ }^{92}$ Out of the 259 members, just six were women (2.3 per cent). Three of these women Cristina Ciontu, Eugenia Iorga and Mariana Celac - came from the FSN: Ciontu, a medical student, and Iorga, a high school teacher, had also been among the founding members of the FSN, while Celac, a well-known architect, had joined the FSN later. The other women were Mariana Dumitrescu, a lawyer from the Party of Social Democracy in Romania, Daniela Tavalica, a lawyer from the Free Democratic Party and Liubita Rachici from the Democratic Union of Serbians from Romania. ${ }^{93}$ The

91 Art. 1 of Decree 81/1990.

92 L. Gheorghiu, 'Twenty-five years since the establishing of the first post-communist parliament - CPUN (25 de ani de la infiintarea primului parlament postdecembrist CPUN)', Cotidianul.ro, 9 February 2015, www.cotidianul.ro/25-de-ani-de-la-infiintareaprimului-parlament-postdecembrist-cpun/.

93 Institutul Revolutiei Romane din Decembrie 1989 (Bucuresti), Documents Regarding the Romanian Revolution from December 1989. The Activity of the Provisory Council of 
CPUN, as the Council of FSN, also had an Executive Office that exercised most of the power. No woman was part of the Executive Office. ${ }^{94}$

The FSN was registered as a political party on 6 February 1990, three days before the CPUN started its activity. Until it ceased to manage the state power, the FSN Council adopted a series of decrees that were indicative of the protectionist and gender-conservative mindset of its members: Decree-Law no. 31 of 18 January 1990, which granted parental leave only to women; ${ }^{95}$ Decree-Law no. 51 of 5 February 1990, which recognised the period when working wives followed their husbands who had to go on a mission abroad as time spent in the workplace for the purposes of seniority; and Decree-Law no. 60 of 7 February 1990, which upheld a different pension age for men and women.

\subsubsection{May 1990-December 1991. Drafting Romania's Post-Communist Constitution}

The story of the drafting of the 1991 Romanian Constitution started in March 1990 when the CPUN decided that the soon-to-be-elected (by popular vote) parliament would mainly have the role of a constituent assembly. ${ }^{96}$ The parliamentary elections were scheduled for 29 May 1990. Apart from a few independent candidates, seventy-three political parties and entities enrolled for the elections of the Chamber of Deputies and sixty enrolled for the election of the Senate. Since there was no electoral threshold (meaning that those enrolled in the electoral race could enter the parliament regardless of how few votes they received), the first Romanian parliament comprised forty political organisations. ${ }^{97}$ The FSN received over 65 per cent of the vote, so it was the dominant political force. The other main political entities that entered parliament were the Democratic Union of Hungarians in Romania (Uniunea Democrata Maghiara din Romania, UDMR) with more than 7 per cent of the vote, the National Liberal Party (Partidul National Liberal, PNL) with more than 6 per cent of the vote, and the Ecologist Movement of Romania

National Unity (1 February - 11 May 1990) [Documente Privind Revoluția Romana din Decembrie 1989. Activitatea Consiliului Provizoriu de Uniune Nationala (1 februarie 11 mai 1990)], vol. I (Cluj-Napoca: MEGA, 2009), pp. 112-116, 123-127.

94 Ibid., p. 147.

95 The leave introduced by Decree 31 was of about nine months' duration, during which women were paid at 65 per cent of their previous wage.

96 See Article 80 of Decree 92/1990.

97 Stanescu-Stanciu, 'Introductive study', p. 44. 
(Miscarea Ecologista din Romania, MER), the Christian Democratic National Peasants' Party (Partidul National Taranesc Crestin-Democrat, PNTCD) and the Alliance for the Union of Romanians (Alianta pentru Unitatea Romanilor, AUR) each with over 2 per cent of the vote. ${ }^{98}$ Some of the opposition parties, such as the National Liberal Party or the Christian Democratic National Peasants' Party, belonged to the category of 'historic parties', meaning parties that had been established during the era of the Romanian monarchy, but had had to stop their activity once the Communist Party took power, and then had started functioning again after the fall of the Ceausescu regime. They were self-defined as anti-communist and were determined to stand against the FSN, which they perceived to be a continuator of the Communist Party, and therefore a party of neo-communist orientation. Against this background, the real split in the first democratically elected parliament after 1989 was between the FSN and the various anti-FSN factions. ${ }^{99}$

On 11 July 1990, during the first meeting of the newly elected parliament to discuss constitutional matters, a Commission for elaborating the project of the Romanian Constitution (the Commission) was appointed. ${ }^{100}$ The Commission was meant to resemble as much as possible the political composition of the parliament. ${ }^{101}$ It consisted of twenty-three MPs: thirteen belonged to the FSN, three to the PNL, two to the UDMR, one member was not politically affiliated and the Ecologist Party of Romania (Partidul Ecologist Roman, PER), the PNTCD, the Agrarian Democratic Party (Partidul Democrat Agrar din Romania, PDAR) and the national minorities had one representative each. Apart from the MPs, the Commission also included five legal experts ${ }^{102}$ who did not have the right to vote in the deliberations. ${ }^{103}$ No woman was part of this Commission. In practice, the Commission enjoyed most of the power over drafting the Romanian Constitution. ${ }^{104}$ Although the Commission was initially nominated only to give the general directions and

\footnotetext{
98 Ibid.

99 Ibid.

100 Pietraru, 'The Romanian constitution of 1991', pp. 156-157.

101 Ibid., p. 157.

102 The Commission was headed by Antonie Iorgovan. See the full composition of the Commission on the Official Webpage of the Romanian Chamber of Deputies, www.cdep.ro/pls/parlam/structura.co?leg=1990\&cam $=0$ \&idc $=87$.

103 Pietraru, 'The Romanian constitution of 1991', p. 157.

104 Focseneanu, The Constitutional History of Romania (1859-2003), pp. 266-269.
} 
structure of the future Constitution, after several months of work, the Commission came up with a rather elaborate draft that had to be further debated by the Constituent Assembly. ${ }^{105}$ The Assembly debated it between February and November 1991 and adopted the Constitution on 21 November 1991. About two weeks later, on 8 December, the Constitution was approved by a national referendum. ${ }^{106}$

Since the Constituent Assembly was the first democratically elected parliament, the fight to include different groups (and interests) in the process of constitution-making coincided with the electoral fight. In this context, the problem of women's participation in drafting the 1991 Constitution should be analysed in the broader context of women's political representation. After the May 1990 elections, only 4.9 per cent of the new parliament was composed of women. ${ }^{107}$ Just three out of the twenty-four elected women-MPs belonged to a historical party, namely the National Liberal Party: two were in the Chamber of Deputies ${ }^{108}$ and one woman was appointed to the Senate on 30 March $1991,{ }^{109}$ so about six months before the adoption of the Constitution by the parliament. Eighteen of the other women belonged to the FSN, including the only female MP who had been a member of the Senate from the very beginning. Two more women belonged to the PER and one woman belonged to the MER. ${ }^{110}$ Nonetheless, in terms of the percentage of women of the total number of MPs from each party, the FSN was not the party with the most women representatives. More precisely, in the Chamber of Deputies 6.96 per cent of FSN members were women compared to 6.89 per cent of PNL, 25 per cent of PER and 8.33 per cent of MER members. In the Senate, although both the FSN

105 Ibid., p. 266.

106 For a detailed description of the constitution-making process, see Pietraru, 'The Romanian constitution of 1991', pp. 151-274.

107 See 'The evolution of women's representation in the parliament of Romania', Electoral Permanent Authority of Romania, Department of Studies, Documentation and Monitoring of the Electoral Process (2013), www.roaep.ro/prezentare/wp-content/uploads/ 2013/04/women_Parliament.pdf, p. 1.

108 Leo Miza Iulia and Șerbanescu Rodica.

109 Tatarescu Maria Sanda. See list of female senators on the Official Webpage of the Romanian Chamber of Deputies, www.cdep.ro/pls/parlam/structura.de?leg=1990\& $\mathrm{cam}=1 \&$ par $=\mathrm{F}$.

110 See full list of female MPs in the Chamber of Deputies on the Official Webpage of the Romanian Chamber of Deputies, www.cdep.ro/pls/parlam/structura.de?leg=1990\& par=F. 
and the PNL had one woman each, this represented 1.28 per cent of the FSN members and 10 per cent of the PNL ones. ${ }^{11}$

As explained in Section 2.3.1, the reasons for this dramatic decrease in women's representation in politics are not easy to understand and more empirical research is needed towards this end. Furthermore, not only were women largely absent during the drafting of the constitution, but previously existing protections, such as the informal rules of the previous regime for promoting women in politics, were not maintained in the new Constitution. This is surprising, and further research is needed to understand why this was the case, given that the 1991 Constitution did set aside special seats for national minorities (see current Article 62(2)). Moreover, as we show further, with the notable exception of Article 26(2), which refers to the right to one's own body and covers the legalisation of abortion, the provisions of the Romanian Constitution reveal a rather gender-conservative vision.

Perhaps the most important provision for women's rights in the 1991 Constitution was the provision regarding the right to freely dispose of one's own body ('unless one infringes on the rights and freedoms of others, on public order or the standards of public morality ${ }^{112}$ ), which covers the protection of a woman's choice to have an abortion. This provision had already been included in the first draft of the Constitution prepared by the all-male Commission. ${ }^{113}$ Thus, although women were not present in the constitutional drafting Commission, women's experiences of dealing with Ceausescu's cruel anti-abortion law did have an impact on the post-1989 constitutional design.

Surprisingly, given the dramatic consequences of Ceausescu's pronatalist policies, the legalisation of abortion was challenged during the debates of the Constituent Assembly. Immediately after 1989, pro-life views from the West, and especially from the USA, started being imported into Romania. ${ }^{114}$ Ioan Alexandru, a male MP and a member

111 We calculated the percentages according to the data available on the Official Webpage of the Romanian Chamber of Deputies, www.cdep.ro/pls/parlam/structura.home?leg= 1990\&idl $=1$.

112 This is the final formulation of the text of Article 26(2) of the RC.

113 The draft can be found in D. Ioncica, O. Stanga and V. Puiu, The Genesis of the Romanian Constitution of 1991: The Works of the Constituent Assembly (Geneza Constitutiei Romaniei 1991: Lucrarile Adunarii Constituante) (Bucuresti: Regia Autonoma 'Monitorul Oficial', 1998), pp. 191-195.

114 See 'The Foundation of Romanian Prolife Movement', on the Official Website of the Pro-Vita Bucuresti Organisation, www.provitabucuresti.ro/english/on-the-foundationof-romanian-prolife-movement. 
of one of the historical parties (PNTCD), after participating in a series of international pro-life events abroad, proposed the introduction of a guarantee of the right to life of the foetus in the Constitution. ${ }^{115}$ Alexandru was a strong supporter of the Christian Orthodox faith and was well known for his illegal religious preaching during communism. In his speech in the Constituent Assembly, he built upon the fact that religion had been marginalised by the communist regime, implying that a return to religion and religious norms, which in his view included prohibiting abortion, would be in complete harmony with the rejection of communism and the return of Romania to the West. ${ }^{116}$ Unfortunately, the way the debates of the Constituent Assembly were recorded (and probably organised) fails to provide the reactions to Alexandru's declarations and the exact reasons for which his proposal was rejected. ${ }^{117}$

One of the few women MPs, Constanta Comisel from the FSN, proposed to amend another gender-related provision already present in the draft prepared by the all-male Commission, namely the provision referring to family. This provision later became Article 44(1) of the Constitution and stated that: 'the family is founded on the freely consented marriage of the spouses, their full equality, as well as the right and duty of the parents to ensure the upbringing, education and instruction of their children'. She proposed to add that, apart from being based on the full equality of the spouses, the family is also based on the right to decide freely on its size. ${ }^{118}$ Although it oddly referred to a right of the family to decide on the spacing and number of its children and not to such a right of women, ${ }^{119}$ this proposed amendment was certainly meant to limit the power of the state to intervene in the reproductive choices of its citizens. As with Alexandru's

115 See Ioncica et al., The Genesis of the Romanian Constitution of 1991, p. 236.

116 Ibid.

117 During the debates of the first draft of the Constitution each interested group of MPs could address his/her colleagues in the Parliament and propose amendments. However, they had to do so in a pre-established order and the MPs in the Parliament could not react to what the speakers proposed. They could only vote for or against the proposals in a subsequent meeting. See Ibid., pp. 211-256. It would be interesting to find out why Alexandru's proposal was rejected: was it because of the negative experience of Ceausescu's pronatalist policies, or were there MPs concerned about women's equality beyond the need to redress the communist regime's legacy on abortion?

118 Ioncica et al., The Genesis of the Romanian Constitution of 1991, p. 240.

119 Such a right was already guaranteed by the Convention on the Elimination of all forms of Discrimination against Women (CEDAW) in Article 16 para. 1 (e). Romania became part of CEDAW in 1982 and did not make any reservations regarding this article, despite prohibiting abortion. 
proposal, however, the available sources do not reveal the precise rationale behind proposing/rejecting such an amendment. ${ }^{120}$

The initial draft of the Constitution prepared by the Commission also referred to citizens' fundamental duties, which included men's duty to defend the country and to serve in the military forces (the text explicitly used only the word 'men' as opposed to 'women'). ${ }^{121}$ This provision was included in the Romanian Constitution in Article 52(2) and remained in the constitutional text until the 2003 revision.

Other provisions of the initial draft of the Constitution contained gender-related provisions and these were included with minor modifications in the final text. They seem nothing else but a reflection of different laws existing during communism. ${ }^{122}$ More specifically, Article 38 of the Constitution, referring to the social protection of labour, guaranteed women not only equal pay for equal work, but also special working conditions, just as communist-era laws used to do. ${ }^{123}$ Further, Article 33, regarding the right to the protection of health, guaranteed the protection of maternity and Article 43, regarding citizens' living standards, guaranteed paid maternity benefits. ${ }^{124}$ Although this latter provision reflected an assumption of collective responsibility for human reproduction, it made no reference to fathers' responsibility to be involved in childcare. Instead, it endorsed a gendered understanding of childcare responsibilities within the family, placing the childcare burden on women. During communism in Romania, maternity leave had been just 112 workdays and no parental leave had been granted. Parental leave was introduced by the FSN immediately after the outbreak of the Romanian Revolution, but was granted only to women, even though men were eligible for parental leave as well in other countries in the region (for example, East Germany and Hungary had had both granted men the possibility of taking parental leave in the 1980 s). ${ }^{125}$ In this context, the

120 The rejection of this amendment is recorded in Ioncica et al., The Genesis of the Romanian Constitution of 1991, p. 254.

121 Ibid., p. 195.

122 For an overview of the relevant communist legislation, see Jinga, Gender and Representation in Communist Romania, pp. 210-213.

123 Ibid.

124 Similarly, the 1965 Constitution, the last constitution of the Communist regime, talked about 'special measures to protect women's work' in Article 18, and in Article 20 it guaranteed paid maternity leave.

125 Saxonberg, Gendering Family Policies in Post-Communist Europe, p. 92; C. Dobos, 'Socio-economic measures to stimulate natality in 'Eastern Europe' (Masuri socioeconomice de stimulare a natalitatii in 'Europa de Est')' in C. Dobos (ed.), The Pronatalist 
gender-related provisions of the Romanian Constitution seem to be the product of their historical context, rather than part of an agenda for promoting women's rights. They reflect the gender-conservative mentality of constitution-makers, as well as the fact that gender equality was not seen as a core value of the male-led transition to liberal democracy.

The new political parties did not seem to put a strong emphasis, if any, on women's issues or on recruiting women. ${ }^{126}$ On the one hand, traditionally, the historic parties did not have a gender-emancipatory agenda. ${ }^{127}$ As Mary Ellen Fischer explains, before communism, Romania was a mostly agricultural society marked by conservative gender norms and the central role of the Orthodox Church in providing models for family arrangements. ${ }^{128}$ Since the vision of the historic political parties encompassed the return to the pre-communist traditional lifestyle and to religion, one might expect their agenda to have also encompassed a return to the traditional gender roles and moral norms existing in that period. ${ }^{129}$ Notwithstanding this expectation, the position of the historic parties regarding women's rights was less clear-cut, and more empirical research is needed to fully understand the vision of gender relations embedded in the political programmes of these parties. For instance, two things that happened in 1991 and 1992 illustrate the ambivalent position of the PNTCD towards gender issues. On the one hand, in 1991 during the debates of the Constituent Assembly, Ion Alexandru, an MP of the party, proposed banning abortion. ${ }^{130}$ On the other hand, the next year, Corneliu Coposu, the party's leader, proposed to Ana Blandiana that she be the candidate of the opposition for the presidential elections (the opposition formed the Democratic Convention, a centre-right electoral alliance, and decided to have one common candidate to run for president). ${ }^{131}$ On this basis, Romanian scholars like Dan Pavel attribute

Politics of Ceausescu Regime (Politica Pronatalista a Regimului Ceausescu), vol. I (Iasi: Polirom, 2010), p. 207.

126 Harsanyi, 'Romania's women', p. 49.

127 Molocea, 'Reconstructing Romanian feminism', pp. 48-49.

128 Fischer, 'From tradition and ideology to elections and competition', pp. 168-169.

129 In this sense see Molocea, 'Reconstructing Romanian feminism', pp. 48-49.

130 See Ioncica et al., The Genesis of the Romanian Constitution of 1991, p. 236.

131 Ultimately, Ana Blandiana refused the nomination. D. Pavel and I. Huiu, 'We Can Succeed Together Only': An Analytical History of the Democratic Convention, 1989-2000 ('Nu Putem Reusi Decit Impreuna': O Istorie Analitica a Conventiei Democratice, 1989-2000) (Iasi: Polirom, 2003), p. 123. 
to Coposu a view of 'authentic democracy' as being that in which 'men and women play an equal role.' ${ }^{132}$

On the other hand, although prima facie more inclined towards promoting gender equality, ${ }^{133}$ the members of the centre-left FSN party that dominated both the parliament and the Commission for elaborating the project of the Romanian Constitution seem to have also been exclusionary towards women. For example, in the parliament meeting of 21 November 1991 when the text of the Constitution was adopted, one of the FSN parliamentarians, ${ }^{134}$ in his speech on the Constitution's importance, emphasised the 'malefic' influence of women on national politics. ${ }^{135}$ As support for his assertion, he contended that the 'cyclic nature' of history explained how, just as during the monarchic period, during communist times 'the country was ruled by a dictator heavily influenced by a woman'. ${ }^{136}$ He did not appear to have been challenged by either his party colleagues or by opposition members.

Moreover, Mary Ellen Fischer, who in her study on women's political representation in Romania conducted interviews with five women from five different political factions in the 1990-1992 parliament, shows that these women were generally unhappy in parliament. They reported that they felt unable to trigger the changes they wanted and that they were generally not taken seriously when they spoke in parliament. ${ }^{137}$ Fischer also reports that women MPs were not allowed to have a separate commission on women's issues. ${ }^{138}$ Instead, a Commission on Labour,

132 D. Pavel, "The myth of "the founding father" of the post-communist democracy Corneliu Coposu (Mitul "parintelui fondator" al democratiei postcomuniste - Corneliu Coposu)' in C. Fulger and T. C. Zarojanu (eds.), The Senior Corneliu Coposu (Seniorul Corneliu Coposu), (Bucuresti: Humanitas, 2014), p. 70.

${ }^{133}$ Harsanyi, 'Romania's women', p. 49.

134 MP Vasile Vacaru.

135 Ioncica et al., The Genesis of the Romanian Constitution of 1991, p. 1058.

136 This is reminiscent of what is generally termed in the Romanian public discourse as the curse of Elenas' according to which throughout history, the politics of the country has been negatively influenced by its rulers' wives or mistresses - who were, coincidentally, all called Elena. More precisely, these women include: Elena Cuza, the wife of Al. Ioan Cuza, the first ruler of Romania after the country was constituted in 1859, Elena Lupescu, for whom King Carol II abdicated in 1940 and finally Elena Ceausescu. For an article discussing 'the curse of Elenas' see M. Ghilezan, 'The curse of Elenas (Blestemul Elenelor)', Observator Cultural no. 489 (28 September 2009), www.observatorcultural.ro/articol/blestemul-elenelor. Ioncica et al., The Genesis of the Romanian Constitution of 1991, p. 1058.

137 Fischer, 'From tradition and ideology to elections and competition', pp. 183-184.

138 Ibid., p. 184. 
Health, Social Protection and the Status of Women in Society was established. Although this Commission should have been concerned with gender-related matters, as its name suggests, there seems to have been no real commitment among its members to promote women's rights and autonomy in deciding over these rights. Not only were women in the minority in this Commission, but the Commission was headed by a man. ${ }^{139}$ Furthermore, women MPs' dissatisfaction with this Commission should be seen as a sign that they did not perceive it as fit to promote their interests. Linking labour, health and social protection with women's rights may well have been a way to undermine the latter and create confusion; for example, if a matter such as women's political representation arose, it would have been unclear where in this list of concerns it would fit.

The question of the international experts invited to give their opinions on the draft of the Romanian Constitution, their gender, and the extent to which they put women's interests on the agenda deserves further research. Antonie Iorgovan - often called 'the father of the Romanian Constitution' - in his 'Odyssey of the Romanian Constitution', which is probably one of the most comprehensive books on the process of drafting the Constitution, discusses the role of international experts in the process of constitution-making. There is no woman listed among these experts and no mention of gender or women's rights. ${ }^{140}$ Likewise, in a re-published edition of his book on Romanian constitutional history, Eleodor Focseneanu brings up the question of international experts and discusses their role and some of their opinions. None of the experts mentioned by Focseneanu are women, and no reference to women's representation or interests is made in this book. ${ }^{141}$

Particularly worthy of further research is the composition and the eventual gender agenda of the Venice Commission, and of the American Bar Association (ABA). The Venice Commission (the European Commission for Democracy through Law) is an advisory body of the Council of Europe composed of constitutional law specialists. Apart from

139 Ibid. See the full list with members on the Official Webpage of the Romanian Chamber of Deputies, www.cdep.ro/pls/parlam/structura.co?leg=1990\&idc $=58$.

140 A. Iorgovan, The Odyssey of Drafting the Constitution (Odiseea Elaborarii Constitutiei) (Targu Mures: Editura Uniunii Vatra Romaneasca, 1998), pp. 66-70.

141 See, e.g., Focseneanu, The Constitutional History of Romania (1859-2003), pp. 274, $277-278$. 
issuing advisory opinions on constitutional reforms in Romania, the Commission was also involved in the constitution-making process of 1990-1991. The ABA also provided advice on the drafting of the Constitution. One of the ABA's reports mentions two workshops during which $A B A$ experts exchanged ideas with the Commission for drafting the Constitution. ${ }^{142}$ Although these ABA experts were all men, and none of them seem to have had the credentials of a gender specialist, ${ }^{143}$ the ABA did send feminist lawyers to CEE. They included the celebrated Justice Ruth Bader Ginsburg and Judge Patricia M. Wald - who at that time were both serving on the bench of the United States Court of Appeals for the District of Columbia Circuit. They both participated in a workshop to discuss the draft of the Lithuanian Constitution in 1992. ${ }^{144}$ Furthermore, in 1993 Judge Wald wrote an article aimed at raising awareness among Central and Eastern European women regarding the importance of getting involved in promoting their interests in the new constitutional texts of the region. ${ }^{145}$ She expressed her support for the women in the region who wanted to keep in their constitutional texts the welfare benefits gained during communism (for example, maternity leave). ${ }^{146}$ Based on the example of the USA, where women's groups could not yet convince decision-makers to grant them comparable benefits, Judge Wald made suggestions about how women in CEE could frame their social and economic rights in their constitutional texts in a way that would ensure that these rights would not remain mere paper pronouncements but would become enforceable. ${ }^{147}$ Researchers interested in the role of women in the constitution-making processes in CEE should further explore the influence of experts such as Judge Wald in order to better understand whether and to what extent women were able to influence constitutional drafting in the region.

${ }^{142}$ See 'Country Strategies for the Rule of Law Program for Albania, Bulgaria, Croatia, Czech Republic, Estonia, Hungary, Latvia, Lithuania, Macedonia, Poland, Romania, and Slovakia. Submitted to the U.S. Agency for International Development', American Bar Association, Central and East European Law Initiative (CEELI), 23 August 1993, on file with the authors, pp. 139, 140.

143 Their names in Ibid.

144 Ibid., p. 102.

145 See P. M. Wald, 'Some unsolicited advice to my women friends in Eastern Europe', SMU Law Review 46(3) (1993), pp. 557-583.

146 Ibid., pp. 558-560.

147 Ibid., pp. 560-563. 


\subsubsection{The 2003 Constitutional Revision. Preparing Romania for NATO and EU Accession}

The first major revision of the Romanian Constitution, and thus far the only successful one, was completed in 2003. It contained a hodgepodge of constitutional amendments meant, first, to ensure compliance with the European Union acquis communautaire and with the preconditions for NATO membership, and thus to smooth over the country's accession to both organisations. ${ }^{148}$ Second, the 1991 Constitution was thought to require some fine-tuning so as to ensure a more harmonious functioning of public authorities, and clarify boundaries between them. In other words, many of the adopted changes were not so much the result of a holistic rethinking of Romania's constitutional commitments as they were piecemeal alterations designed to bring the country in line with external requirements or to clarify relations and remove tensions between various state institutions. What also characterised the 2003 revision was a broad consensus among elites regarding the need for reform and its general, European direction. ${ }^{149}$ The revision has also been characterised as a top-down endeavour, ${ }^{150}$ and as one resulting in hasty drafting uninformed by public discussion or civic involvement. ${ }^{151}$

The revision process followed the arduous amendment procedure laid out in Title VI (currently Title VII) of the 1991 Constitution. This required a two-thirds majority vote of all members of the two houses of parliament, as well as a successful vote in a national referendum with over 50 per cent turnout. The Constitution also contains a so-called eternity clause (current Article 152), which prevents amendment of certain fundamental state characteristics or changes that result in the suppression of the citizens' fundamental rights and freedoms, or of the safeguards thereof. As will be seen, the latter became relevant during

148 See V. Duculescu and R. Adam, 'Romania' in A. E. Kellermann et al. (eds.), The Impact of EU Accession on the Legal Orders of New EU Member States and (Pre-)Candidate Countries: Hopes and Fears (The Hague: TMC Asser Press, 2006), pp. 114-118; M. Hein and S. Gherghina, 'Romania' in A. Fruhstorfer and M. Hein (eds.), Constitutional Politics in Central and Eastern Europe: From Post-Socialist Transition to the Reform of Political Systems (Wiesbaden: Springer VS, 2016), p. 175.

149 S. Gherghina and S. Miscoiu, 'Crowd-sourced legislation and politics', Problems of PostCommunism 63(1) (2016), p. 27.

150 Ibid.

151 B. Iancu, 'Separation of powers and the rule of law in Romania: The crisis in concepts and contexts' in A. von Bogdandy and P. Sonnevend (eds.), Constitutional Crisis in the European Constitutional Area (Oxford: Hart Publishing, 2015), p. 159. 
the attempted 2013 revision, when the Constitutional Court found several of the proposed changes unconstitutional on account of their breaching this unamendable provision. In accordance with this procedure, a joint parliamentary committee was set up in June 2002 to work on the draft law on constitutional revision. Four out of twenty-two members were women: three were members of the ruling social-democratic party (the successor of FSN) and one belonged to the extreme-right party Great Romania Party (Partidul Romania Mare, PRM). ${ }^{152}$

A novelty during the 2003 revision process was the creation of a national Constitutional Forum (Forumul Constitutional) to deliberate on potential changes and ensure the involvement of civil society and regular citizens. On the civil society side, the Forum was led by the Pro Democracy Association (Asociatia Pro Democratia, APD), a nongovernmental organisation pushing for improved democratic standards, greater citizen participation in decision-making and more transparency in governance. ${ }^{153}$ The Forum set up a website and organised public consultations in several major cities across the country, as well as workshops and other consultations. A summary of its work and recommendations was included in its final report, presented to the Chamber of Deputies. $^{154}$

In terms of women's involvement in the Forum, a female MP - Amelia Mursez - was responsible for coordinating the project on the parliament's side, and one of the two APD coordinators was also a woman, Eugenia Rotaru. More significant for determining the gender-sensitivity of such an experiment would be to know the extent to which women were involved in the deliberations, whether as individuals or as civil society representatives, as well as the extent to which their views were taken into account and influenced the final recommendations of the Forum. The Forum's report does not provide enough information to determine this, and it is likely that such observations were not recorded

152 See the composition of the committee on the Official Webpage of the Romanian Chamber of Deputies, www.cdep.ro/pls/parlam/structura.co?leg=2000\&cam=0\&idc=27.

153 For more on APD's mission, see the Official Website of the Pro Democracy Association (Asociatia Pro Democratia, APD), www.apd.ro/ro_RO/despre-noi-3. According to the official page of the Romanian Chamber of Deputies, the Association did formally list 'equality of opportunity for women to participate in public life' among its stated goals upon registration. See: www.cdep.ro/informatii_publice/ong.chest_aprobate?f_idc=206. However, the APD does not pursue an explicitly feminist agenda.

${ }^{154}$ Constitutional Forum: Final Report (Forumul Constitutional: Raport Final), 2003, on file with the authors. 
during the Forum's proceedings. The report does include lists of participants at the Forum's five regional meetings, of which a little over 40 per cent (75 out of 185) were women, three of which are listed as representing women's organisations. ${ }^{155}$ The latter are not recorded to have put forth specific agendas or claims, however, and without a record of the deliberations themselves, it is difficult to assess their input and impact. The Forum's report merely aggregates the opinions and proposals expressed by participants, whether individuals or NGOs.

Substantively, the Forum's recommendations were concentrated around clarifying the scope of certain rights and institutional competences. There seems not to have been a preoccupation with the gendered impact of the provisions under review, even when it may have been highly pertinent. For example, proposals around equality focused on that between citizens and non-citizens; ${ }^{156}$ discussions around the right to life and integrity of the person focused on whether to reintroduce the death penalty; ${ }^{157}$ the right to privacy was seen through the lens of public figures and the inviolability of the home; ${ }^{158}$ reform of service in the military revolved around its length and obligatory nature, ${ }^{159}$ and so on. Even vis-àvis provisions which would have been clear candidates for bringing in a gender equality perspective, the Forum's report records little to no such input. For example, the discussion of electoral rights appears to have revolved around the age of candidates for various public offices or the right to vote of prisoners. ${ }^{160}$ Similarly, calls to improve state protection of the family, and possibly to recognise alternative forms of union to marriage, were motivated by concern for the adequate protection of children and communal property. ${ }^{161}$ An exception appears to have come in the form of proposals by trade unions to remove sex-based discrimination and ensure equality of opportunity and treatment in employment, said to have been supported by 13.72 per cent of participants. ${ }^{162}$ It is

155 The women's organisations in question were: Women for Positive Action, Tolerance and Education (Femei pentru Actiuni Pozitive, Toleranta si Educatie (FAPTE)), the Romanian Association for Woman's Promotion (Asociatia pentru Promovarea Femeii din Romania (APFR)) and the Women's Association of Romania, Dolj county. Ibid.

156 Ibid., p. 42.

157 Ibid., pp. 42-43.

158 Ibid., pp. 44-45.

159 Ibid., pp. 55-56.

160 Ibid., pp. $48-49$.

161 Ibid., pp. 52-53.

162 Ibid., p. 51. 
difficult to know to what extent the Forum's recommendations, which were in any case meant to be consultative, influenced the work of the parliamentary Commission on constitutional revision. There was no formal requirement for parliament to respond to or provide an account for how it dealt with the Forum's report. Opinions differ between those who view the 2003 revision process as no less elite-driven than past constitution-making, ${ }^{163}$ others who either believe the Forum to have had a marginal influence at best, ${ }^{164}$ and those who think it did influence the constitutional agenda. ${ }^{165}$

Law 429/2003 lists all the changes adopted in the aftermath of the process of constitutional revision. With regard to women's rights, several amendments bear highlighting. Article 16 of the RC on 'Equality of rights' was modified to affirm women's equal access to official positions; Article 16(3) thus reads: 'Access to public, civil, or military positions or dignities may be granted, according to the law, to persons whose citizenship is Romanian and whose domicile is in Romania. The Romanian State shall guarantee equal opportunities for men and women to occupy such positions and dignities'. The change was justified by the President of the Commission on constitutional revision simply as reflecting 'a tendency characteristic of European democracy'; ${ }^{166}$ or, as then-MP and future Prime Minister Emil Boc put it, by 'the opening up of the constitutional framework in preparation for Romania's accession to the European Union and NATO'. ${ }^{167}$ There were competing proposals surrounding this Article, with one proposal to eliminate the positive duty of the State (in favour of a general statement of equality between men and women) defeated in favour of the current formulation, the latter taken to be a better signal of the State's commitment to ensuring equality. ${ }^{168}$ The

163 Iancu, 'Separation of powers and the rule of law in Romania', p. 159.

164 Gherghina and Hein, 'Romania', p. 182.

165 See Arpad Todor, cited in Blokker, 'The Romanian constitution and civic engagement', 450. See also R. Goellner, 'Die Verfassungsentwicklung in Rumaenien nach 1990' in E. Bos and K. Pocza (eds.), Verfassungsgebung in konsolidierten Demokratien (BadenBaden: Nomos Verlag, 2014), pp. 175-191.

166 See the speech of MP Valer Dorneanu in Session of the Chamber of Deputies of 18 June 2003, www.cdep.ro/pls/steno/steno.stenograma?ids $=5493 \& \mathrm{idm}=2$. Interestingly, there was a call to extend the same principle of equality between national minorities as well, including via affirmative action measures. The attempt, however, was unsuccessful. See the speech of MP Varga Atilla in Session of the Chamber of Deputies of 24 June 2003, www.cdep.ro/pls/steno/steno.stenograma?ids=5496\&idm $=6$.

167 MP Emil Boc in Session of the Chamber of Deputies of 30 June 2003, www.cdep.ro/pls/ steno/steno.stenograma? ids $=5502 \& i d m=2$.

168 See debates in Session of the Chamber of Deputies of 24 June 2003. 
link to European accession is even clearer when considering that a new paragraph was simultaneously introduced in Article 16(4), which dealt with the right of European Union citizens to vote in and stand for local elections. Article 52 (currently Article 55), on 'Defence of the country', was modified to remove the reference to mandatory conscription for men only. The article now refers to voluntary military service and the possibility of conscription of 'citizens' - all in line with NATO standards on professional armies. ${ }^{169}$

Just as significant for our purposes are those provisions not changed in the 2003 revision. These included references to maternity but not paternity leave (current Article 47); the text of the Article in question was modified to include a general reference to state assistance to which citizens were entitled by law, but rendering the reference to maternity leave gender-neutral was not discussed. ${ }^{170}$ Similarly, references to 'measures of social protection' for employees, including 'working conditions for women and young people' (current Article 41) were retained.

The proposed amendments were adopted in a national referendum in October 2003, which at the last minute had to be extended over two days to ensure the required participation threshold would be met. It is undeniable that, despite the innovation of including the Constitutional Forum, the 2003 revision process lacked transparency and inclusiveness. Not only was it the case that '[a]ll discussions took place behind closed doors in the parliamentary committee in charge of constitutional revision', ${ }^{171}$ but the general consensus among elites and public opinion regarding the need for revision - identified as a requirement of European accession prevented a more critical look at the Constitution. The absence of a clear feminist voice in the deliberations around the revision meant that women's rights were not on the agenda in any meaningful way.

Several further observations are relevant here. The first is that Romania's 2003 constitutional moment was not principally focused on women's rights. Instead, central to this constitutional revision were

169 See NATO, 'Romania - National Report', 2004, www.nato.int/ims/2004/win/romania.pdf. The report explicitly lists constitutional and legislative change in Romania as a step forward, noting that: 'The legal ground by which women are also allowed to serve on a voluntary basis, represents one of the first regulations designed to ensure that all citizens have free access to military service, regardless of gender'.

170 See Report on the Results of the Mediation Commission, PL 227/2003, 8 September 2003, on the Official Website of the Romanian Chamber of Deputies, www.cdep.ro/ proiecte/2003/200/20/7/rm227.pdf.

171 Gherghina and Hein, 'Romania', p. 184. 
amendments regarding the functioning of certain state institutions and the separation of powers, the rule of law, certain rights (such as those of national minorities) and military service, while any enhanced protection of gender equality was secondary at best. Thus, despite almost half of the 152 articles of the original 1991 Constitution being altered to a greater or lesser degree, ${ }^{172}$ women's rights were not central on the revision agenda. The changes that were introduced were either general (see the guarantee of equality in Article 16(3)) or directly tied to NATO military requirements (see the amendment of Article 52). The EU, while promoting gender equality as an accession criterion, appears to have been more focused on concrete legislation and implementation, such as promoting anti-trafficking measures or the creation of an anti-discrimination body, rather than on constitutional reform. ${ }^{173}$

Furthermore, the story of Romania's European accession should be understood in the broader context of the EU's eastern enlargement and the way in which gender mainstreaming was pursued within that broader project. It has been noted that EU enlargement presented Central and Eastern European women's movements with the opportunity to pursue legislative changes and, more generally, to raise women's rights in the public sphere. ${ }^{174}$ By promoting gender equality as a European requirement, women's rights organisations could thus legitimate a discourse and project that had hitherto remained on the fringes of politics. ${ }^{175}$ To a certain extent, this was also the case in Romania, where women's rights NGOs could tap into European funds to pursue a feminist agenda as well as access training and resources towards playing a more active role in the political sphere. ${ }^{176}$ Nevertheless, the extent to which governments in

172 Ibid., p. 175.

173 See 2003 Regular Report on Romania's Progress towards Accession, European Commission, 2003, www.ec.europa.eu/neighbourhood-enlargement/sites/near/files/archives/pdf/ key_documents/2003/rr_ro_final_en.pdf, pp. 24, 28.

174 S. Roth, 'Introduction' in S. Roth (ed.), Gender Politics in the Expanding European Union: Mobilization, Inclusion, Exclusion (Oxford: Berghahn Books, 2008), p. 9. This strategy was not limited to women's rights advocates and was instead employed by democratic-liberal elites more generally; the latter framed Europeanisation as an unmitigated good and 'any resistance was viewed as being triggered by anti-democratic forces, either longing for the ancien régime, or moved by populist, nationalistic, and authoritarian motives'. W. Sadurski, Constitutionalism and the Enlargement of Europe (Oxford University Press, 2012), p. 20.

175 Roth, 'Introduction', p. 9.

176 A. Nimu, 'Nongovernmental organizations for women's rights: Contextual approaches, personal experiences (Organizatii neguvernamentale pentru drepturile femeilor: abordari contextuale, experiente personale)', in A. Nimu et al. (eds.), Civil Society, Democracy and Institution Building (Societate Civila, Democratie si Constructie Institutionala) (Iasi: 
Central and Eastern Europe, and thus also in Romania, were truly responsive to these demands, or were instead paying lip service in order not to jeopardise accession, was always a concern. ${ }^{177}$ Furthermore, the empowerment of women's rights NGOs through EU accession, at least in Romania, appears to have been a temporary win. These organisations remained dependent on European funds and often shaped their agendas to suit EU priorities. As these funds began to dry up and were not replaced by support from the Romanian state, women's NGOs started restraining their activities. Thus, the $\mathrm{EU}$ aid failed to become fully sustainable. ${ }^{178}$

Another observation here is that the EU accession of Central and Eastern European states was a mixed bag in terms of gender equality. To quote one observer, 'from a gender perspective, the EU expansion is contradictory. ${ }^{179}$ On the one hand, European standards legitimised and emboldened the push for improved legal protections for women. At the same time, however, the supranational organisation these countries were joining did not have a perfect track record on women's rights. As noted previously, Romania and other former communist new member states had made gains on this front that were ahead of those of some of the EU's older member states, such as on employment and labour protections; thus, 'national adaptation to the ostensibly gender-neutral political and economic standards of the EU led to an exclusion of women from labour markets and the public sphere'. ${ }^{180}$ This is not to deny the overall positive impact of EU accession on the pursuit of gender equality in Romania. It is simply to draw attention to the more complex relationship between the supranational body and the legal protections for women's rights in former communist member states.

\subsubsection{The 2013 Attempted Constitutional Revision: Responding to Previous Constitutional Crises}

The fourth constitutional moment revolved around the 2013 attempted revision of the Constitution. The context for this attempt was very

Polirom, 2016), p. 110. Nimu, a feminist political scientist, would become involved in the 2013 Constitutional Forum (see Section 2.3.4, this volume).

177 See Roth,'Introduction', p. 9; Borza, 'A lacking legitimacy in the transposition of the EU's equal opportunity directives'.

178 See Nimu, 'Nongovernmental organizations for women's rights'.

179 Roth, 'Introduction', p. 7.

180 Ibid. 
different from that of 2003. The 2013 revision was initiated in the aftermath of a series of constitutional crises in previous years and reflected a sense that the country's semi-presidential system, coupled with the textual ambiguity surrounding executive functions, needed to be revisited in order to ensure more stable government. ${ }^{181}$ Thus, even more so than had been the case in 2003 when external conditionalities were at play, the impetus for the 2013 constitutional moment may be seen as elite-driven and aimed at resolving immediate political concerns rather than fostering a national dialogue and comprehensive constitutional review. ${ }^{182}$

The 2013 revision was to follow the same arduous amendment procedure that had been pursued in 2003. Thus, in February 2013 a joint parliamentary committee was set up to draft the required amendment law. The committee's work and deliberations were not to be public. Once a draft was to be agreed upon, it needed to be adopted, first by a two-thirds majority vote in both houses of parliament and then in a national referendum. Only one of the twenty-one permanent committee members (and only two of the seven supplementary members) were female. ${ }^{183}$ Two other female members left the committee before it completed its work. ${ }^{184}$

181 On the constitutional crises preceding the 2013 attempt at constitutional revision, see V. Perju, 'The Romanian double executive and the 2012 constitutional crisis', International Journal of Constitutional Law 13(1) (2015), pp. 246-278.

182 Gherghina and Miscoiu, 'Crowd-sourced legislation and politics', p. 27. See also discussion in Blokker, 'The Romanian constitution and civic engagement', pp. 450-453.

183 The former was a member of the National Liberal Party (PNL) and also acted as one of four Vice-Presidents of the Committee, whereas the latter were members of the PNL and the Hungarian minority parties UDMR, respectively. See the composition of the Committees on the Official Website of the Chamber of Deputies, www.cdep.ro/pls/parlam/ structura.co?leg=2012\&cam $=0 \& i d c=114$. Such special committees are set up by parliament on an as-needed basis and their members are appointed by party leaders according to each party's parliamentary strength. Only one of the three female MPs, UDMR's Biró Rozália-Ibolya, has had a more substantive legislative agenda regarding women's rights (though not exclusively). She has been among the initiators of laws on awareness of women's equality and breast cancer and on monitoring and reform of health and social services. See Biró Rozália-Ibolya's legislative initiatives in the 2012-2016 legislature on the Official Website of the Chamber of Deputies, www.cdep.ro/pls/parlam/structura . $\mathrm{mp}$ ?idm=19\&cam=1\&leg=2012\&pag=2\&idl=1\&prn=0\&par=. More recently, she has also been among the initiators of a law to strengthen domestic violence legislation. See Biró Rozália-Ibolya, Legislative initiatives in the 2016-present legislature, www.cdep.ro/ $\mathrm{pls} /$ parlam/structura.mp?idm=35\&cam=2\&leg=2016\&pag=2\&idl=1\&prn=0\&par=.

184 These were Alina Gorghiu, who would become the first president of a major political party (PNL) in Romania in 2014, and Gabriela-Maria Podasca, a social democrat who has been among the initiators of a law to strengthen the legislation on equality of opportunity between men and women. See Gabriela-Maria Podasca, Legislative 
A new Constitutional Forum was also set up, which sought to facilitate even more public participation than its counterpart had in 2003. It was again led by the APD through its president, Cristian Parvulescu, and organised public meetings and workshops in various cities, as well as an online platform through which citizens could submit their proposals and discuss issues. Parvulescu explicitly stated that he saw the Forum as pursuing 'the widest debate possible', along three axes - geographic, thematic and academic - which would bring together not only NGOs and experts, but also individuals; he also saw the Forum as politically unaffiliated. ${ }^{185}$ The Forum's report was coordinated by Todor Arpad, who was also present in the joint parliamentary committee, and Irina Ionescu, both APD members, and it benefitted from the input of several feminist experts, such as Mihaela Miroiu and Andrada Nimu. The Forum's working method included public and virtual debates; its final report also integrated insights from questionnaires (administered at the public meetings) as well as from opinion polls. ${ }^{186}$ The report synthesised all these and more (including 'informal discussions ... with event participants' and 'discussions with Venice Commission experts') but admitted that the volume of proposals (over 5,000 pages of documentation) meant that it was not fully representative of the proposals made; it further admitted that 'whether proposals are reflected in the report also depended on the number and significance of the organisations having proposed different points of view'. ${ }^{187}$ The representativeness of the Forum's deliberations has been called into question, not only because a limited number of questionnaires were sent out (550) and a small number of online proposals, of varying quality, were received (400), but also and primarily because its recommendations displayed a coherence which the public consultations had never had. ${ }^{188}$

initiatives in the 2012-2016 legislature, www.cdep.ro/pls/parlam/structura.mp?idm= $292 \& \mathrm{cam}=2 \& l e g=2012 \& p a g=2 \& i d l=1 \& p r n=0 \& p a r=$.

185 A. Boghiceanu, 'The constitutional forum will have three axes: Territorial, thematic and academic (Forumul Constitutional va avea Trei Axe: Teritoriala, Tematica si Academica)', Adevarul, 19 February 2013, www.adevarul.ro/news/politica/forumul-constitu tional-trei-axe-teritoriala-tematica-academica-1_512318e900f5182b8579d06e/ index.html.

186 Constitutional Forum: Final Report (Forum Constitutional: Raport Final), 2013, p. 51. On file with the authors.

187 Ibid., p. 23.

188 See critique in V. Perju, 'The analysis of the Final Report of the Constitutional Forum 2013 (Part I) (Analiza Raportului Final al Forumului Constitutional 2013 (Partea I))', 
Unlike in 2003, however, there seems to have been a distinct effort made to address gender equality. Rather than reflecting an official policy, this was due to the opening up of the 2013 Forum to wider sections of society, in particular providing ample opportunities for civil society organisations and academics to have their say. ${ }^{189}$ Among the NGOs having made proposals to the Forum, we also find women's organisations and even feminist ones:

- the Filia Center (Centrul Filia), which describes itself as an advocacy and activism-based feminist organisation supporting equality of opportunities, gender equality and women's emancipation; ${ }^{190}$

- the FRONT Association (Asociatia FRONT), which describes itself as being composed of young feminists militating for gender equality and combatting other forms of discrimination; ${ }^{191}$

- the Partnership Centre for Equality (Centrul Parteneriat pentru Egalitate), which fights for equality of opportunities between women and men, particularly in the areas of labour, education, culture and health; ${ }^{192}$

- the Contraceptive and Sexual Education Society (Societatea de Educatie Contraceptiva si Sexuala), active in promoting family planning and sex education; ${ }^{193}$

- the Mothers for Mothers Association (Asociatia Mame pentru Mame), which promotes the physical and emotional health of women and children and runs awareness-raising and advocacy campaigns in this area; ${ }^{194}$

- the ACCEPT Association (Asociatia ACCEPT), Romania's main LGBT rights organisation (see also Section 2.3.5). ${ }^{195}$

Contributors.ro, 30 May 2013, www.contributors.ro/dezbatere/analiza-raportului-finalal-forumului-constitutional-2013-partea-i/.

189 See remarks by Cristian Parvulescu, the Forum's President, in Boghiceanu, 'The constitutional forum will have three axes'. Perju makes the point that the Forum report drafters sought to present coherent recommendations that did not reflect the sometimes contradictory outcomes of public consultations. For example, whereas the report recommended the election of the President by a parliamentary vote, public opinion overwhelmingly favoured the former's direct election.

190 The Official Website of Centrul Filia, www.centrulfilia.ro/misiune/.

191 The Official Website of Asociatia Front, www.feminism-romania.ro/despre-noi/aso ciaia-front.

192 The Official Website of Centrul Parteneriat pentru Egalitate, www.cpe.ro/despre-noi/.

193 The Official Website of Societatea de Educatie Contraceptiva si Sexuala, www.secsromania.wordpress.com.

194 The Official Website of Asociatia Mame pentru Mame, www.mamepentrumame.ro.

195 The Official Website of Asociatia ACCEPT, www.accept-romania.ro/en. 
These organisations are listed in the Forum's final report as having, together with other NGOs (notably those active in the area of civic activism and education), supported two proposals. The first of these relates to the definition of the state as secular (Romanian: laic), so as to clearly separate state and religion and protect individual rights. ${ }^{196}$ The second proposal was to expand Article 4's list of grounds on which discrimination is forbidden to include prohibiting discrimination on the basis of sexual orientation. ${ }^{197}$ Neither of these proposals would be reflected in the final revision draft submitted to the Constitutional Court for certification. In fact, this final draft would have recognised the contributions of the Orthodox Church and the other churches to the founding and modernisation of the state (draft Article 1(1)'); it would also have made the list of prohibited discrimination grounds more open-ended, but without explicitly including sexual orientation (draft Article 4(2)).

Also as part of the 2013 Forum, a conference was organised in the Romanian Senate in April 2013 on the theme of 'Minority Rights in the Romanian Constitution. Gender Equality, Equality of Opportunity' (thus lumping together two very different topics for reform). The Forum's final report lists 'gender and minority quotas, as well as rejecting domestic violence and gender hatred' among the most important themes emerging from this conference. ${ }^{198}$ Mihaela Miroiu, a speaker at the conference and author of some of the Forum's recommendations, pushed strongly for the explicit recognition of, and measures favouring, gender equality. Among these were the amendment of the following: Article 1, so as to recognise women's equal access to electoral mandates and elected office, as well as equal professional and social responsibilities; ${ }^{199}$ Article 8 , so as to clearly mention women and men in the context of political pluralism and political parties; ${ }^{200}$ and Articles 36 and 37, on the right to vote and to be elected, respectively, again so as to explicitly list women and men. ${ }^{201}$ The issue of gender quotas in parliament was also part of the Forum's deliberations. ${ }^{202}$ Other proposals related to women's rights were to modify Article 34 on the right to health so as to include references to

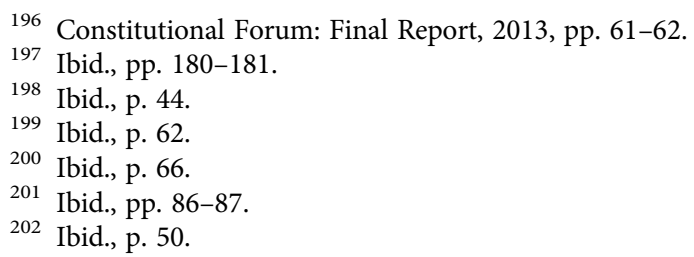


prenatal and birth-related medical care; ${ }^{203}$ economic freedom on equal terms between women and men; ${ }^{204}$ explicitly banning gender-based discrimination at work; ${ }^{205}$ and requiring that the Ombudsman's office hire gender equality experts. ${ }^{206}$ There was also a proposal (also Miroiu's) to amend Article 26 on private and family life so as to state that public authorities have a duty to protect family members from 'abuses and violence. ${ }^{207}$ A hotly debated provision was Article 48 on the family, with several different proposals registered on amending it - whether to redefine family as being exclusively between a man and a woman, or to explicitly allow marriage equality and/or civil partnerships. ${ }^{208}$ As will be seen in Section 2.3.5, these debates foreshadowed a fight for constitutional reform on the matter, based on a popular initiative.

The extent to which the Forum's recommendations were taken into account is again difficult to ascertain, both because of the many filters through which they passed and due to the similarities between some of the Forum's proposals and those already prepared by MPs. ${ }^{209}$ Moreover, a number of civil society organisations, among which were a number of women's and pro-life organisations (notably the Women's Association of Romania and the Alliance of Families in Romania) publicly lamented the Forum's lack of representativeness, transparency, and accuracy in representing their positions. ${ }^{210}$ According to these organisations, the Forum leaders were not elected, they communicated poorly with organisations and on at least one occasion they provided insufficient space to accommodate all organisations during a public event. Without public records of the Forum's deliberations and decision-making procedures, however, it is difficult to evaluate the validity of their objections.

203 Ibid., p. 84.

204 Ibid., p. 96.

205 Ibid., p. 97.

206 Ibid., p. 104.

207 Ibid., pp. 75, 219. Neither this nor other proposals made explicit reference to genderbased violence, however.

208 Ibid., pp. 250-255.

209 Gherghina and Hein, 'Romania', p. 190.

210 'A part of the Romanian civil society denounces the deficient fashion in which the process of constitutional reform has taken place so far (O parte a societatii civile din Romania reclama modul defectuos in care s-a desfasurat pana in prezent procesul de reforma constitutionala)', Romanian Global News, 2 July 2017, on file with the authors, www.rgnpress.ro/rgn_13/categorii/politic/9789-o-parte-a-societii-civile-din-romaniareclam-modul-defectuos-in-care-s-a-desfasurat-pana-in-prezent-procesul-de-reformaconstitutionala-.html. 
The final draft law on amending the Constitution was reviewed in March 2014 by the Venice Commission, which had been involved in the revision process at the invitation of the Romanian Government. ${ }^{211}$ In its Opinion, the Commission did not have anything to say on proposals regarding gender equality and was concerned instead with assessing the proposed changes to the balance of powers, in particular vis-à-vis the double executive, as well as certain individual rights and rule of law protections. Even in the case of provisions that could have received a gender-sensitive reading, such as Article 48 on the definition of the family, the Commission accepted the draft law's retention of the old formulation $^{212}$ and stated that, in the absence of a European standard on the matter, it was for Romanian authorities to determine the issue. ${ }^{213}$

A rather more substantial brake in the revision process came in midFebruary 2014, when the Romanian Constitutional Court issued an ex officio opinion on the draft law to amend the Constitution. ${ }^{214}$ The Court found a number of key amendments - such as attempts to restrict its competence or to increase the powers of the Prime Minister vis-à-vis those of the President - unconstitutional and thus, to a considerable degree, took the wind out of the reformers' sails. As the final draft had not incorporated the feminist proposals discussed by the Constitutional Forum, there was no evaluation of their constitutionality.

The initial plan was for the entire revision process to be completed by the end of 2015 at the latest. At least at the moment the process was set in motion, the political cards seemed to favour it, as the ruling coalition government enjoyed the requisite supermajority in parliament and could presumably easily adopt the draft amendments (subject to final approval in a national referendum). This changed not just with the aforementioned Constitutional Court rejection of several of the proposed amendments, but also following the exit of the National Liberal Party from the

${ }^{211}$ European Commission for Democracy through Law (Venice Commission), Opinion on the Draft Law on the Review of the Constitution of Romania, 21-22 March 2014 ('Venice Commission Opinion').

212 Article 48(1) declares: 'The family is founded on the freely consented marriage of the spouses, their full equality, as well as the right and duty of the parents to ensure the upbringing, education and instruction of their children'.

213 Venice Commission Opinion, para. 86.

214 Decision 80/2014. The Constitutional Court can issue such ex officio opinions on proposals for the amendment of the Constitution. See Article 146(a) of the RC and Articles 19-23 and Law 47/1992. 
governing coalition in late February $2014 .^{215}$ Thus, in spite of the significant time and effort invested, the constitutional reforms set in motion in 2013 ultimately failed.

With regard to the 2013 attempted constitutional revision, women's involvement may appear marginally more successful due to the prominence of certain feminist voices, notably Miroiu's, during the proceedings of the Constitutional Forum. However, hers was not a dominant voice in a process that was more concerned with removing constitutional ambiguity, which had previously led to institutional conflicts and political instability. Moreover, Miroiu represents only one strand of Romanian feminism (white and liberal, as opposed to, for example, leftist or Romani feminism). ${ }^{216}$ Furthermore, the final draft of the law on amending the Constitution contained no mention of gender equality or women's rights, focusing instead primarily on territorial reform and changes to the power relations between institutions. ${ }^{217}$ In other words, despite a more concerted effort to at least entertain potential changes to the Constitution that would better protect women's rights, the 2013 attempted revision was again not focused on improving gender equality.

What the 2013 moment also shows, however, is that not enough had changed from the previous constitutional revision process. While better organised, civil society still lacked adequate political know-how and legal expertise needed to become meaningfully involved in the workings of the Constitutional Forum or otherwise lobby lawmakers. Feminist organisations were no exception. Furthermore, and unlike in 2003, there was not a similar elite consensus on the need for constitutional amendment, ${ }^{218}$ nor external pressure towards it. Neither the Venice Commission nor the

${ }^{215}$ Gherghina and Hein, 'Romania', p. 191.

216 For an introduction to the state of Romani feminism in Romania, see C. Gheorghe, L. Mark and E. Vincze, 'Towards an anti-racist feminism for social justice in Romania' in A. Kóczé et al (eds.), The Romani Women's Movement: Struggles and Debates in Central and Eastern Europe, 1st edn (Abingdon, Oxon and New York: Routledge, 2018), pp. 111-134.

217 See Legislative Proposal for the Revision of the Romanian Constitution, L233/2014 (Propunere Legislativa de Revizuire a Constitutiei Romaniei, L233/2014), 7 February 2014, on the Official Website of the Romanian Senate www.senat.ro/legis/PDF/2014/ 14L233FG.pdf.

218 See, for instance, the views of Simina Tanasescu, who opposed the revision, arguing that what was required was a change in mentalities and better enforcement of existing constitutional provisions. S. Tanasescu, 'The revision of the constitution is not a panacea and we should not have too high expectations from a simple modification of legal rules ('Revizuirea constitutiei nu este un panaceu si nu ar trebui sa avem asteptari prea mari de la o simpla modificare de norme juridice)', Pandectele Romane (12) (2013), pp. 15-18, 
Romanian Constitutional Court made any references to gender equality in their interventions, thus depriving feminist activists of additional external support for their proposals. The fact remains that, like in 2003, inscribing women's rights and gender equality on the agenda for constitutional reform was difficult to achieve, even more so given the more immediate political goals animating the process.

The preceding discussion of the 2003 and 2013 constitutional revision moments thus highlights the dearth of female voices during both processes, as well as the marginality of gender equality among the issues up for review. Even the two Constitutional Forums, which ran in parallel to the formal review procedure and were meant to allow public deliberation on and input into the amendment process, did not significantly empower women as constitution-makers. While the 2013 Forum clearly incorporated greater diversity of views, including on women's rights, its recommendations were not necessarily more consequential than those of its predecessor.

\subsubsection{5 and Beyond: Battles Over the Definition of Family}

As seen in Sections 2.3.1-2.3.4, constitution-making in Romania has been generally an elite-driven process. ${ }^{219}$ Although certain participatory mechanisms such as the Constitutional Forum have been employed, these have been rather unsuccessful at bringing about change. A more recent participatory experience comes in the form of a 2015 citizens' initiative to amend the Constitution. Revising the Constitution through this procedure is not easy. The first step is for the citizens' initiative to collect the signatures of at least 500,000 citizens eligible to vote, ${ }^{220}$ distributed across all counties. ${ }^{221}$ After this, the Constitutional Court must check whether the collection of the signatures meets the legal

and 'Should the Romanian constitution be revised? (Trebuie revizuita Constitutia Romaniei?)', Dreptul (5) (2014), pp. 11-13.

219 See Pietraru, 'The Romanian Constitution of 1991'; Focseneanu, The Constitutional History of Romania (1859-2003). On this, see also C. Parau, 'Romania's transnational constitution: A tradition of elite learning and self-empowerment' in D. Galligan and M. Versteeg (eds.), The Social and Political Foundations of Constitutions (Cambridge University Press, 2013), pp. 497-531.

220 Article 150(1) of the RC.

221 More precisely, according to Article 150(2), 'the citizens who initiate the revision of the Constitution must belong to at least half the number of the counties in the country, and in each of the respective counties or in the Municipality of Bucharest, at least 20,000 signatures must be recorded in support of this initiative'. 
requirements and whether such an initiative would breach the eternity clause enshrined in the Constitution, which, among other things, limits any revision that would result 'in the suppression of the citizens' fundamental rights and freedoms, or of the safeguards thereof. ${ }^{222}$ If the initiative passes this constitutional review, the next step requires its adoption by both chambers of the parliament by a majority of at least two thirds of the members of each chamber. ${ }^{223}$ Then, the Constitutional Court must rule once again on the constitutionality of the proposal (to again check the constitutionality of the proposed amendments, in the form adopted by parliament and the procedure of adoption). ${ }^{224}$ If declared constitutional, the revision must then be approved by a referendum to be finally adopted. ${ }^{225}$

No organisation or group had previously managed to launch a citizens' initiative. In 2015, an association of conservative NGOs known as the Coalition for the Family (Coalitia pentru Familie, CpF) succeeded in gathering 'three million signatures ${ }^{226}$ to review Article 48 of the Romanian Constitution on the family, and define it as based on the marriage between a man and a woman. ${ }^{227}$ The aim of such a revision was to prevent the legalisation of same-sex marriages in Romania and to ensure that 'gender stereotypes are constitutionally enshrined'. ${ }^{28}$ The $\mathrm{CpF}$ defines itself as 'a civic initiative without legal personality,

222 Article 152(2) of the RC.

223 Article 151(1) of the RC.

224 Article 7(5) of Law 189/1999.

225 More precisely, Article 151(3) of RC requires that the referendum should take place 'within 30 days of the date of passing the draft or proposal of revision'.

${ }^{226}$ Although in the public sphere the CpF talks about 'three million signatures', the total number of valid signatures was 2,698,477. See Decision 580/2016 of the Constitutional Court of Romania, para. 32.

227 More specifically, Article 48 (1) reads as follows: 'The family is founded on the freely consented marriage of the spouses, their full equality, as well as the right and duty of the parents to ensure the upbringing, education and instruction of their children'. The $\mathrm{CpF}$ has proposed the following reformulation: 'The family is founded on the freely consented marriage between a man and a woman, their full equality, as well as the right and duty of the parents to ensure the upbringing, education and instruction of their children'. (emphasis added). The text of the legislative proposal can be found of the Official Website of the Romanian Chamber of Deputies: www.cdep.ro/pls/proiecte/upl_ pck2015.proiect?nr $=127 \& a n=2017$.

228 Gheorghiu (Civic Platform Together): ‘Gender ideology has become a state policy in Romania (Gheorghiu (Platforma Civică Împreună): Ideologia de gen a devenit în România politică de stat),' AGERPRES, 3 September 2018, www.agerpres.ro/social/2018/ 09/03/gheorghiu-platforma-civica-impreuna-ideologia-de-gen-a-devenit-in-romaniapolitica-de-stat-169742. 
independent of any political party and non-affiliated to any religious creed, open to those who share family values, ${ }^{229}$ yet its member organisations generally have a conservative, right-wing agenda that includes objectives such as supporting religious education in schools, restricting abortion, or promoting Christian values. ${ }^{230}$ Moreover, an overview of its social media presence shows that the Coalition for the Family generally endorses and often praises the policies of right-wing leaders such as US President Donald Trump. ${ }^{231}$ The Coalition is also supported by two American conservative organisations that specialise in constitutional litigation, namely the Liberty Council ${ }^{232}$ and the Alliance Defending Freedom (ADF) International. ${ }^{233}$ Both organisations have lawyers of Romanian origin, such as the Liberty Council's Harry Mihet, the lawyer of Kim Davis, the former Rowan County, Kentucky Clerk who refused to issue marriage licenses to same-sex couples after the US Supreme Court legalized same-sex marriage in $2015 .^{234}$ Peter Costea, another example, was directly involved in lobbying for the introduction of the definition of marriage as a union between a man and a woman in Romania's New Civil Code of $2009^{235}$ and, in 2006, was the leader of another citizens' initiative to define marriage as between a man and a woman in the Romanian Constitution; this initiative was unsuccessful at that time. ${ }^{236}$

229 Our translation. See the Official Website of the CpF, www.coalitiapentrufamilie.ro/ despre-coalitia-pentru-familie/.

${ }^{230}$ See a list with the associations on Ibid., www.coalitiapentrufamilie.ro/despre-coalitiapentru-familie/membri/.

231 See, e.g., the Facebook page of CpF, www.facebook.com/coalitiapentrufamilie/.

232 See 'Liberty Counsel defends natural marriage in Romania', press release on the Official Website of Liberty Council, 23 November 2016, www.lc.org/newsroom/details/112316liberty-counsel-defends-natural-marriage-in-romania-1.

233 See 'One man and one woman - Romanian referendum on marriage definition', 25 April 2017, press release on the Official Website of ADF International, www.adfinternational .org/detailspages/press-release-details/one-man-and-one-woman-romanian-referendumon-marriage-definition/.

234 B. Tashman,'Liberty Counsel invokes communist Romania to denounce "persecution" of Kim Davis', Right Wing Watch, 8 September 2015, www.rightwingwatch.org/post/libertycounsel-invokes-communist-romania-to-denounce-persecution-of-kim-davis/.

235 'Romania adopts strong civil codes protecting marriage', Official Website of Alliance Defending Freedom, 20 July 2009, www.adfmedia.org/News/PRDetail/2680.

${ }^{236}$ More precisely, the initiative was launched by the Alliance of Romania's Families (Alianta Familiilor din Romania, AFR), led by Costea. However, it failed to pass the validity requirements (i.e. gathering sufficient signatures from at least twenty-one of Romania's forty counties). AFR also tried to lobby the Commission to review the Constitution in 2013. For more information, see the Official Statement of the AFR (on file with 
As of the time of this writing, the $\mathrm{CpF}$ initiative has met a similar fate. Although it passed two constitutional checks by the Constitutional Court (in June 2016 and in July $2018^{237}$ ) and it was adopted by a majority of over two thirds in both chambers of the Parliament, the initiative ultimately failed as the referendum for its adoption did not meet the 30 per cent participation quorum for its validity. ${ }^{238}$

The presence of women in this constitutional moment was unprecedented. Women mobilised both for and against the proposed constitutional revision. This is perhaps not surprising given that, in general, women are better represented in NGOs and that the proposed revision touched upon gender-related matters. One member organisation of the $\mathrm{CpF}$ is specifically a women's organisation, namely the Union of Women from Bihor, a county in north-western Romania. The organisation was founded in 1993 by Miorita Sateanu, a woman engineer from the region. ${ }^{239}$ On its face, the Union of Women from Bihor can be considered a women's rights organisation. However, a closer look reveals that the Union militates for limiting women's roles to those of mothers and family carers. In a 2004 guide to women's NGOs written by the AnA - the only self-declared feminist organisation in Romania in the 1990s - the Union of Women from Bihor is listed as an organisation aiming to 'respect women's rights [and] to promote them in the political, economic, social and cultural life. ${ }^{240}$ In the same guide, however, the Union is also listed as aiming to improve the living standards of the family by emphasizing the role of woman within it'. ${ }^{241}$ The Union is very active at the local level; for example, in 2013 and 2014 it organised the

the authors) www.variantacojocaru.ro/ConstitutiaPoporului/propuneri/propunere-AliantaFamiliilor-din-Romania.pdf.

237 See Decision 580/2016 and Decision 539/2018.

238 E. Brodeală, 'Human rights should not be subject to a popular vote: Lessons from Romania's failed anti-LGBT referendum', OxHRH (blog), 30 October 2018, http://ohrh .law.ox.ac.uk/human-rights-should-not-be-subject-to-a-popular-vote-lessons-fromromanias-failed-anti-lgbt-referendum/.

239 A. Costea, 'New president at the Union of Women from Bihor - Miorita Sateanu Retired (Presedinte nou la Uniunea Femeilor din-Bihor - Miorita Sateanu s-a retras din functie)," Crisana, 14 June 2014, www.crisana.ro/stiri/social-9/presedinte-nou-la-uniuneafemeilor-din-bihor-miorita-sateanu-s-a-retras-din-functie-15117.html.

240 'Women and civil society - The NGO Guide 2004 (Femeile si societatea civila - Ghidul Organizatiilor Nonguvernamentale 2004)', Anasaf.ro, www.anasaf.ro/ro/ONG/U-Z/uniunea femeilor.html. (As of the time of this writing, however, the organisation's website appears to no longer exist.)

241 Ibid. 
March for Life to advocate banning abortion, organised campaigns on non-violence for young people, ${ }^{242}$ educated them towards a 'traditional family life ${ }^{243}$ and took part in events to combat violence against women. $^{244}$

Moreover, while the leader of the $\mathrm{CpF}$ (Mihai Gheorghiu) is a man, several women have been particularly visible in public debates over the revision of the Constitution. These include: Liana Stanciu, a radio and television personality and the president of an association militating for the teaching of (Christian Orthodox) religion in Romanian schools; ${ }^{245}$ Adina Portaru, an attorney of Romanian origin working for the American conservative organisation ADF International; ${ }^{246}$ Sophia Kuby, director of European Union advocacy for ADF International; ${ }^{247}$ Ana Corina Sacrieru, a lawyer in Vrancea Bar and the spokesperson of CpF; and Ioana Picos, who runs the organisation Pro-Family Feminism. The image of Picos is particularly relevant to understanding the vision of the $\mathrm{CpF}$. Picos has appeared on several occasions in the national media defending the 'traditional family' and advocating the banning of abortion. She was also a leading figure associated with the 2017 March for Life, the biggest such event organised in Romania. ${ }^{248}$ The event was fully supported by

${ }^{242}$ See 'The Union of Women from Bihor - Archives (Uniunea Femeilor Din Bihor, Arhiva)', BihorStiri.Ro, www.bihorstiri.ro/tag/uniunea-femeilor-bihor.

243 A. Costea, 'Hundreds of students responded to the invitation of the Union of Women from Bihor - They celebrated the Family Day through debates (Sute de elevi au raspuns invitatiei Uniunii Femeilor din Bihor - Au sarbatorit Ziua Familiei prin dezbateri)', Crisana, 15 May 2017, www.crisana.ro/stiri/eveniment-1/sute-de-elevi-au-raspuns-invitatiei-uniu nii-femeilor-bihor-au-sarbatorit-ziua-familiei-prin-dezbateri-157538.html.

244 See Press Release - PSD Bihor (Comunicat de Presa - PSD Bihor), AGERPRES, 12 November 2014, www.agerpres.ro/comunicate/2017/11/26/comunicat-de-presa-psdbihor-11-31-03.

245 The association 'Parents for religious teaching (Parinti pentru Ora de Religie)', www.oradereligie.ro/despre-noi.

246 Her profile on the Official Website of ADF International, www.adfinternational.org/ detailspages/biography-details/adina-portaru.

247 See Sophia Kuby, ADF International (Brussels) on Romania's marriage referendum: 'Those who claim that same-sex couples and married opposite-sex couples should be treated identically must demonstrate that it is not the best for children to be raised by their own mother and father', Official Website of CpF, 26 April 2017, www.coalitiapentrufamilie.ro/2017/04/26/sophia-kuby-adf-international-brussels-romaniasmarriage-referendum-claim-sex-couples-married-opposite-sex-couples-treated-identicallymust-d/.

248 More about the views and activities of Ioana Picos can be found on her Facebook page titled 'Feminism Pro Familie', www.facebook.com/feminismprofamilie. 
the Romanian Orthodox Church and other religious denominations, as well as by the $\mathrm{CpF}$.

The religious motivation of the $\mathrm{CpF}$ ties into its agenda, which goes beyond the banning of same-sex marriage. It encompasses the restriction of access to abortion and reproductive rights more broadly, increasing parental leaves, granting financial incentives for mothers with more than one child and tax benefits for married families or for those who care for children or other dependants. ${ }^{249}$ Interestingly, the discourse of the $\mathrm{CpF}$ and of its conservative partners, such as the organisers of the March for Life, states that they aim to protect women and their rights. For example, the theme of the March for Life 2017 was: 'Help the mother and child! They depend on you'. According to the organisers, the theme 'has provided the opportunity to debate the necessity, possibility and efficiency of supporting women in pregnancy crisis. ${ }^{250}$ Furthermore, inspired by their US counterparts and probably aware that, given the legacy of Ceausescu's pronatalist policy, a legal ban on abortion would not be easy to implement in Romania, the organisers emphasised that the March for Life and other similar events 'do not demand a legal ban on abortion, and they do not support any form of violence against the woman'. ${ }^{251}$ Instead, according to the organisers, these activities should 'raise awareness of the reality of pregnancy crisis, educate about the scientific truth that life begins at conception and promote a supportive attitude towards women so that they can give birth to the life they are carrying in their wombs'. ${ }^{252}$ Thus, instead of demanding a ban on abortion, the pro-lifers have proposed establishing 'pregnancy crisis' cabinets that would provide women with counselling meant to convince them to renounce abortion. A legislative proposal put forward by conservative organisations in 2012 had also required mandatory counselling in case of 'pregnancy crisis' and was seen by gender equality supporters as a way to traumatise women for life. ${ }^{253}$

${ }^{249}$ See the Official Website of CpF, www.coalitiapentrufamilie.ro/50-propuneri-de-masuripolitici-publice-privind-familia.

250 Press Release: 'The March for Life 2017 in Romania: 110,000 ... participants in 138 cities', The Official Website of the Romanian March for Life, 27 March 2017, www.marsulpentruviata.ro/press-release-march-life-2017-romania-110000-de-partici pants-138-cities.

251 Ibid.

252 Ibid.

253 G. Andreescu, 'The draft law regarding the life-long trauma of women requesting abortion services (Proiectul de lege privind traumatizarea pe viata a femeilor care solicita intreruperea sarcinii)', Noua Revista de Drepturile Omului 8(1) (2012), pp. 28-48. 
It would not be a stretch, therefore, to expect more proposals to limit women's reproductive freedom from the $\mathrm{CpF}$ in the future.

The debates over the proposed constitutional review that took place in the Chamber of Deputies are representative of the CpF's genderconservative agenda. ${ }^{254}$ The initiative to revise the Romanian Constitution was debated in the Chamber of Deputies in March 2017 and was voted on in May 2017. The majority of MPs who spoke during the March debates supported the initiative. They saw it as the expression of the people's sovereignty, as a way of protecting family values 'that lie at the heart of Romanian and European identity', as a way of defending Romania's and Europe's Christian heritage and the nation or as a way of clarifying legislation and strengthening the idea that same-sex marriage is prohibited in Romania. ${ }^{255}$ In his speech to support the CpF proposal, one of the male MPs from the Alliance of Liberals and Democrats (Alianta Liberalilor si Democratilor, ALDE), Varujan Vosganian, specifically pointed to traditional gender roles and emphasised that Romania 'pays tribute to the gentle spirit of maternity and the protective one of paternity ${ }^{256}$ and that family should thus be defined in its traditional sense as a marriage between a man and a woman. ${ }^{257}$ During the same debates, there was just one MP who spoke out against the constitutional amendment, namely Gabriel Andronache from the National Liberal Party. The PNL had asked for a revision of the text of the citizens' initiative so that it would define marriage as the union between a man and a woman, and not family, since family, in its view, had a broader meaning. ${ }^{258}$ Although Andronache did not mention the rights of samesex couples, he mentioned that the proposed constitutional review would

254 The Senate's debates over the same constitutional review took place on 11 September 2018 and are equally representative as they mirror, in most part, the debates that took place in the Chamber of Deputies. We do not discuss them here out of space concerns. See the Transcript of the Senate Debate from 11 September 2018, www.senat.ro/ stenograme.aspx.

255 See 'Transcript of the Chamber of Deputies Debate from 27 March 2017 regarding the Legislative Proposal to Review the Romanian Constitution - Pl-x 127/2017', on the Official Webpage of the Romanian Chamber of Deputies, www.cdep.ro/pls/steno/steno .stenograma?ids $=7764 \&$ idm $=12$.

${ }^{256}$ Ibid.

257 Ibid.

258 The proposed amendment reads as follows: 'The family is entitled to protection from society and the state through economic and social measures, including through marriage. Marriage is the freely consented union between a man and a woman, based on the equality of the spouses, as well as the right and duty of the parents to ensure the upbringing, education and instruction of their children' (our translation). Ibid. 
'breach the rights of others'. ${ }^{259}$ He then emphasised that during the debates related to the drafting of the 2009 Civil Code, there had been an agreement that the definition of family based on heterosexual marriage would not be constitutionalised. He also warned that this constitutional review was just the first step in the restriction of the rights of certain groups and that the final goal was to 'restrain women's fundamental rights in Romania'. ${ }^{260}$ Although he did not mention which women's rights he meant, he was likely hinting at the restriction of abortion, another important objective of the Coalition for Family.

The legislative proposal to review the Constitution was passed in the Chamber of Deputies on Europe Day (9 May) 2017, with 232 votes for, 22 votes against and 13 abstentions (three MPs did not vote). After this, there were a series of speeches explaining the vote. The MPs who took the floor mainly reiterated the points about preserving the national identity of Romania, its Christian values and the gendered nature of the family - all of which had been raised in the previous parliamentary debates. ${ }^{261}$ The speeches were closed by a female MP, Florica Chereches, who was also the only female MP to take the floor and express her opinion on the $\mathrm{CpF}$ proposal. Chereches, a well-known supporter of pro-life and pro-family values, was behind previous initiatives meant to restrict women's access to abortion ${ }^{262}$ and had previously proposed the revision of Article 48 so as to define marriage as between a man and a woman. ${ }^{263}$ In her speech she emphasised that she was a strong family supporter since she was a 'wife and a mother of four'. ${ }^{264}$ She also

259 Ibid

260 Ibid.

261 See 'Transcript of the Chamber of Deputies Debate from 9 May 2017 regarding the Legislative Proposal to Review the Romanian Constitution - Pl-x 127/2017', www.cdep.ro/pls/steno/steno.stenograma?ids=7782\&idm $=6,009$.

262 See D. Constantinovici, 'PNL MP Florica Chereches reactivates the anti-abortion law proposed by PDL in 2012 (Deputatul PNL Florica Chereches reactiveaza legea anti-avort propusa de PDL in 2012)', Pandoras.Realitatea.Net, 4 February 2014, www.pandoras.realitatea.net/life/deputatul-pnl-forica-chereches-reactiveaza-legea-antiavort-propusa-de-pdl-in-2012-32375.html.

263 'The new constitution: The amendment according to which family is based on the freelyconsented marriage between a man and a woman adopted (Noua constitutie: amendamentul conform caruia familia se intemeiaza pe casatoria liber consimtita intre un barbat si o femeie, adoptat)', Mediafax, 5 June 2013, www.mediafax.ro/social/noua-constitutieamendamentul-conform-caruia-familia-se-intemeiaza-pe-casatoria-liber-consimtitaintre-un-barbat-si-o-femeie-adoptat-10930830.

264 'Transcript of the Chamber of Deputies Debate from 9 May 2017 regarding the Legislative Proposal to Review the Romanian Constitution - Pl-x 127/2017'. 
qualified the vote that took place on Europe Day as a 'historical' one, meant to stand as a reminder that 'Europe was founded on Christian principles'. ${ }^{265}$

Against this background, it is not surprising that women's rights organisations worked together with LGBT organisations to counteract the initiative of the CpF. Feminist activism in post-communist Romania has never been stronger than during these debates. The development of gender studies as a field of study, ${ }^{266}$ access to gender studies programmes abroad and the overall development of civil society in Romania have given birth to a new generation of feminists and supporters of women's rights. Unlike their predecessors in the 1990s and early 2000s, this new generation of feminists has framed its demands around third-wave feminism and does not shy away from making its voice heard in the public sphere. These feminists have particularly emphasised the need to include intersectional claims on the feminist agenda, such as the protection of Roma or lesbian women's rights. Representative organisations for third-wave feminism in Romania include FRONT Association and FILIA Centre (both mentioned in Section 2.3.4), as well as E-Romnja, an organisation promoting the rights of Roma women. ${ }^{267}$ These organisations reacted promptly to the $\mathrm{CpF}$ initiative. They participated in public debates and protests against the initiative, signed open letters and joined other actions meant to stop the revision of the Constitution.

Notably, these organisations also joined other interested NGOs and sent an amicus curiae brief to the Romanian Constitutional Court, asking the Court to reject the $\mathrm{CpF}$ proposal. ${ }^{268}$ Their efforts were not successful, however, and the Constitutional Court, in a very brief and poorly drafted decision, stated that the proposed constitutional changes would 'not suppress citizens' fundamental rights'. ${ }^{269}$ The

265 Ibid.

266 On this see, e.g., M. Miroiu, 'A mind of our own. Gender studies in Romania', Aspasia 4 (1) (2010), pp. 157-167.

267 See the Official Website of E-Romanja NGO, www.e-romnja.ro/e-romnja/about_ eromnja.html.

268 See the brief on the Official Website of ACCEPT NGO, www.acceptromania.ro/blog/ 2016/07/18/28-de-organizatii-romanesti-si-internationale-de-drepturile-omului-criticainitiativa-de-modificare-a-definitiei-familiei-din-constitutia-romaniei/.

269 See Decision 580/2016. 
NGOs thus continued their activity. They sent an open letter to the parliament petitioning it to reject the proposal ${ }^{270}$ and have demanded that the Romanian president and the presidents of the Senate and the Chamber of Deputies ask for an opinion on the proposal from the Venice Commission. ${ }^{271}$ At the same time, they started a serious public campaign against the referendum.

Other organisations advocating for women's rights, but not necessarily from a (third-wave) feminist perspective, joined the efforts against the modification of Article 48 of the Constitution. These included:

- two organisations founded right after the 1989 Revolution, the AnA Society for Feminist Analyses, ${ }^{272}$ and the Society for Contraceptive and Sexual Education (SECS), the first Romanian NGO operating in the field of family planning, also founded in 1990 (mentioned in Section 2.3.4);

- two organisations from outside the capital city, the Association for Liberty and Equality of Gender (Asociatia pentru Libertate si Egalitate de Gen, ALEG), an NGO from the region of Sibiu founded in 2004 that fights gender-based violence, ${ }^{273}$ and the Equality and Human Rights Action Centre (Centrul de Actiune pentru Egalitate si Drepturile Omului, ACTEDO), a human rights organisation from Cluj-Napoca, founded in 2013 by young activists, that focuses on gender equality; ${ }^{274}$

- the Partnership for Equality Centre (also mentioned in Section 2.3.4), an organisation that originated from restructuring the women's programme of the Open Society Foundation Romania in 2002;

- the Romanian Women's Lobby, which is the Romanian branch of the European Women's Lobby established in $2007 ;^{275}$

- the Euroregional Centre for Public Initiatives (ECPI), a Bucharestbased organisation founded in 2008 to promote human rights and

270 'The civil society asks the parliament to respect and protect the diversity of family in Romania (Societatea civila cere parlamentului sa respecte si sa protejeze diversitatea familiei in Romania), Official Website of FRONT Association, 7 November 2016, www.feminism-romania.ro/activism/38-ong/1280-societatea-civila-cere-parlamentuluisa-respecte-si-sa-protejeze-diversitatea-familiei-in-romania.

271 See the request on the Official Website of ACCEPT NGO, www.acceptromania.ro/blog/ 2017/04/06/societatea-civila-solicita-opinia-comisiei-de-la-venetia-pe-tema-redefiniriifamiliei/.

272 See the Official Website of the AnA NGO, www.anasaf.ro. (At the time of this writing, however, this website appears to be unclaimed.)

273 See the Official Website of ALEG NGO, www.aleg-romania.eu/en/.

274 See the Official Website of ACTEDO NGO, www.actedo.org/.

275 See the Official Website of the Women's Lobby, www.womenlobby.org/RomanianWomen-s-Lobby. 
non-discrimination, with particular focus on the promotion of sexual and reproductive rights; ${ }^{276}$

- the Association of Mothers for Mothers, a Bucharest-based organisation founded in 2010 to promote women's rights related to motherhood (also mentioned in Section 2.3.4);

- and Asociatia Necuvinte, a Bucharest-based NGO founded in 2013 to fight domestic violence. ${ }^{277}$

Among these organisations, ECPI has close connections to Romania's main LGBT association, ACCEPT. Its Program Director is Iustina Ionescu, a female lawyer who also works for ACCEPT. Ionescu specialises in anti-discrimination law, is a member of the European Commission's European Network of Legal Experts in the field of Gender Equality and Non-Discrimination, and an expert in reproductive and sexual rights. In 2016, Ionescu brought the Coman case before the Constitutional Court, a case concerning the legal recognition of same-sex marriages concluded abroad. ${ }^{278}$ The Coman case sparked an intense discussion in Romanian society and was debated in tandem with the constitutional review proposal. Ionescu works closely with Romanita Iordache, another female lawyer affiliated with ACCEPT. Iordache is also a gender expert and, together with Ionescu, is the author of some of the most important reports on gender equality in Romania. ${ }^{279}$ They also drafted ACCEPT's main legal documents opposing the constitutional review. Due to their legal expertise, Ionescu and Iordache are likely to play an important role in the future constitutional debates on genderrelated matters.

Along with third-wave feminists and women's NGOs, liberal feminists from academia also publicly opposed the CpF proposal. Mihaela Miroiu spoke vehemently against any discrimination based on sexual orientation and the intervention of the Church in regulating private relationships. ${ }^{280}$

${ }^{276}$ See the Official Website of the ECPI NGO, www.ecpi.ro/sample-page-3/echipa/ ?lang=en.

277 See the Official Website of the Necuvinte NGO, www.necuvinte.ro/mission-vision/ ?lang=en.

278 For more details about the case, see the Official Website of ACCEPT NGO, www.coman.acceptromania.ro/cazul-coman-va-ajunge-la-curtea-de-justitie-a-uniuniieuropene/?lang=en.

279 See the Official Website of the European Network of Legal Experts in Gender Equality and Non-Discrimination, www.equalitylaw.eu/country/romania.

280 See, e.g., M. Miroiu and T. Baconschi, 'The traditional family in the constitution (Familia traditionala in constitutie)', Revista 22, 16 May 2017, www.revista22.ro/70262750/ 
Likewise, Oana Baluta, a former student of Miroiu and an important figure in the debates around the constitutional definition of the family, emphasised that the attacks of the $\mathrm{CpF}$ are directed not only against LGBT people, but also against women's rights and in particular against their reproductive autonomy. ${ }^{281}$ Baluta is also one of the founders of the RESPECT platform, an association of over 100 organisations, civic movements and citizens that aimed to stop the revision of the Constitution. Since the threat posed by the $\mathrm{CpF}$ was not immediately evident, the platform was formed only in June 2017, after the Chamber of Deputies adopted the proposal to modify the Constitution. ${ }^{282}$ Women's rights, and in particular women's reproductive and sexual rights and the right to be free from domestic violence, are central to the agenda of RESPECT. ${ }^{283}$

The presence of women in this last constitutional moment was unprecedented. The citizens' initiative procedure to review the Constitution has at its core the idea of participatory decision-making. Moreover, traditionally women are much better represented in civil society than in politics or other state structures. However, whereas this most recent constitutional review process enabled women to be actors in the constitutional debates, its content was meant to strengthen a patriarchal structure - the heterosexual family based on strict gender roles - that has historically placed men in a position of superiority and women in a position of inferiority. This explains to a great extent why the feminist

familia-tradiional-n-constituie.html; I. E. Dogioiu, 'Traditional family? Jesus does not say anything on this subject. We care more about customs than people (Familia traditionala? Iisus nu spune nimic pe aceasta tema. Ne sunt mai dragi cutumele decat oamenii)', Ziare.com, 12 May 2017, www.ziare.com/social/romani/familia-traditionalaiisus-nu-spune-nimic-pe-aceasta-tema-ne-sunt-mai-dragi-cutumele-decat-oameniiinterviu-1465223.

281 See, e.g., O. Baluta, 'Three millions of boyars (Trei milioane de jupani)', Adevarul.Ro (blog), 28 May 2016, www.adevarul.ro/news/politica/trei-milioane-jupani-1_ 574952b55ab6550cb8634cea/index.html; F. Dragan, 'Oana Baluta: CpF wants to impose a totalitarian vision regarding people's personal choices (Oana Baluta: $\mathrm{CpF}$ vrea sa impuna o viziune totala asupra alegerilor private ale oamenilor)', Romania Libera, 8 July 2017, www.romanialibera.ro/special/documentare/oana-baluta-cpf-vrea-sa-impuna-oviziune-totala-asupra-alegerilor-private-ale-oamenilor-457127.

282 R. Filip, 'I attended the launching of RESPECT Platform to find out how will they stop the Coalition for Family (Am fost la lansarea platformei RESPECT ca sa aflu cum vor opri Coalitia pentru Familie', Vice, 8 June 2017, www.vice.com/ro/article/ywzw9w/ce-eplatforma-respect.

283 See the Official Website of Platforma Respect, www.platformarespect.ro. 
mobilisation during this constitutional moment was unparalleled. Feminists belonging to different ideological traditions, women's rights supporters and other interested groups reacted strongly to the proposed constitutional revision. They created networks and platforms for action, and they started a serious campaign to counter the objectives of the $\mathrm{CpF}$. This was a key moment in the development of a women's movement in Romania. It is certain that their involvement in constitutional debates represents an important learning experience for women's rights groups. It will perhaps be the moment when they begin viewing the Constitution as a key site for the struggle to promote women's equality.

\subsection{Conclusion}

This chapter has traced the evolution of women's rights on the Romanian constitutional agenda from the early days of the country's democratic transition to today. It first delineated the legal status of Romanian women pre-1989 and the specificities of the communist legacy in the country, especially vis-à-vis women's involvement in the political domain. It then described five key moments in the evolution of the Romanian Constitution and their impact on the constitutional protection of gender equality: the period between 1989 and 1990, when the first constitutional documents of post-communist Romania came into force; the period of drafting and adoption of the 1991 Constitution; the successful 2003 constitutional revision; the failed 2013 attempt at constitutional revision; and the process to amend the Constitution on the basis of a popular initiative started in 2015. While we have referred to these as five crucial turning points in Romania's constitutional evolution, these should be seen neither as self-contained events - they are instead deeply contextual and tied into broader societal processes nor as the only sites of constitutional change; indeed, we refer throughout to other proposals for amendment over the years. With regard to each of these moments, the chapter discussed the relevant actors and dynamics, as well as the question of women's impact on constitutional protections.

Overall, we showed that, until very recently, women were largely under-represented among Romanian constitution-makers and did not have any significant influence over the process of adopting or revising the Constitution. Equally, gender-progressive provisions have not been a priority for the male-dominated bodies in charge of drafting or amending the Constitution. Furthermore, by looking at certain key constitutional 
battles, past and present, the chapter highlighted the specificities of engendering the Romanian Constitution, placing this process within its transitional, post-communist, European and transatlantic contexts. Often, the story we have told has been an uneven one, revealing a nascent and often struggling civil society and political sphere in which the fight for gender equality was rarely a priority. We have also sought to signal that many important battles still loom ahead for gender equality defenders in Romania. Whether the Romanian women's rights movement has matured enough to raise a confident and effective voice within these battles remains to be seen. Our hope, however, is that this chapter can provide a useful overview of the gains and losses of striving for gender equality in post-communist Romania, and that it will inspire future research into women's struggle for constitutional change.

\section{Bibliography}

\section{Books}

Ackerman B., 1991. We the People: Foundations (Cambridge, MA: Harvard University Press).

Baciu A., 1988. The Role of the 1923 Constitution in Consolidating National Unity. The Evolution of the Constitutional Matter in Interwar Romania (Rolul Constitutiei din 1923 in Consolidarea Unitatiii Nationale. Evolutia Problemei Constitutionale in Romania Interbelica) (Bucuresti: Editura Stiintifica si Enciclopedica).

Blandiana A., 2013. False Treatise of Manipulation (Fals Tratat de Manipulare) (Bucuresti: Humanitas).

Bucur I., 2014. Year 1990: Parties, Ideologies and Political Mobilization (Anul 1990: Partide, Ideologii si Mobilizare Politica) (Bucuresti: IRRD).

Chiva C., 2017. Gender, Institutions and Political Representation: Reproducing Male Dominance in Europe's New Democracies (London: Palgrave Macmillan).

Cornea D., 2006. The Power of Fragility (Puterea Fragilitatii) (Bucuresti: Humanitas).

2009. Journal: Last Notebooks (Jurnal: Ultimele Caiete) (Bucuresti: Fundatia Academia Civica, Centrul International de Studii asupra Comunismului).

Corrin C. (ed.), 1992. Superwomen and the Double Burden: Women's Experience of Change in Central and Eastern Europe and the Former Soviet Union (London: Scarlet Press).

Deletant D., 1995. Ceausescu and the Securitate: Coercion and Dissent in Romania, 1965-1989 (London: Hurst Hurst \& Company). 
Focseneanu E., 2009. The Constitutional History of Romania (1859-2003) [Istoria Constitutionala a Romaniei (1859-2003)], vol. III (self-published by E. Focseneanu).

Funk N. and Mueller M. (eds.), 1993. Gender Politics and Post-Communism: Reflections from Eastern Europe and the Former Soviet Union (New York: Routledge).

Gallagher T., 2008. Modern Romania: The End of Communism, the Failure of Democratic Reform, and the Theft of a Nation (New York University Press). Ioncica D., Stanga O. and Puiu V., 1998. The Genesis of the Romanian Constitution of 1991: The Works of the Constituent Assembly (Geneza Constitutiei Romaniei 1991: Lucrarile Adunarii Constituante) (Bucuresti: Regia Autonoma 'Monitorul Oficial').

Iorgovan A., 1998. The Odyssey of Drafting the Constitution (Odiseea Elaborarii Constitutiei) (Targu Mures: Editura Uniunii Vatra Romaneasca).

Jaquette J. S. and Wolchik S. L. (eds.), 1998. Women and Democracy: Latin America and Central and Eastern Europe (Baltimore, MD: Johns Hopkins University Press).

Jinga L. M., 2015. Gender and Representation in Communist Romania: 1944-1989 (Gen si Reprezentare in Romania Comunista: 1944-1989) (Iasi: Polirom).

Kligman G., 1998. The Politics of Duplicity: Controlling Reproduction in Ceausescu's Romania (Berkeley: University of California Press).

Lane J. -E., 1996. Constitutions and Political Theory (Manchester University Press).

Levy R., 2001. Ana Pauker: The Rise and Fall of a Jewish Communist (Berkeley: University of California Press).

Long K. S., 1996. We All Fought for Freedom: Women in Poland's Solidarity Movement (Boulder, CO: Westview Press).

Miroiu M., 2004. The Road to Autonomy. Political Feminist Theories (Drumul catre Autonomie. Teorii Politice Feministe) (Iasi: Polirom).

Pavel D. and Huiu I., 2003. 'We Can Succeed Together Only': An Analytical History of the Democratic Convention, 1989-2000 ('Nu Putem Reuşi Decit Impreuna': O Istorie Analitica a Conventiei Democratice, 1989-2000) (Iasi: Polirom).

Penn S., 2006. Solidarity's Secret:The Women Who Defeated Communism in Poland (Ann Arbor: University of Michigan Press).

Putnam R. D., 1976. The Comparative Study of Political Elites (Englewood Cliffs, NJ: Prentice-Hall).

Reading A., 1992. Polish Women, Solidarity and Feminism (Basingstoke, Hampshire: MacMillan).

Rueschemeyer M. (ed.), 1998. Women in the Politics of Postcommunist Eastern Europe (Armonk, NY: M. E. Sharpe).

Sadurski W., 2012. Constitutionalism and the Enlargement of Europe (Oxford University Press). 
2014. Rights Before Courts: A Study of Constitutional Courts in Postcommunist States of Central and Eastern Europe, 2nd edn (Dordrecht, Netherlands: Springer).

Sadurski W., Czarnota A. and Krygier M. (eds.), 2005. Rethinking the Rule of Law after Communism (Budapest and New York: Central European University Press).

Saxonberg S., 2014. Gendering Family Policies in Post-Communist Europe: A Historical-Institutional Analysis (Basingstoke: Palgrave Macmillan).

Siani-Davies P., 2005. The Romanian Revolution of December 1989 (Ithaca, NY: Cornell University Press).

Waylen G., 2007. Engendering Transitions: Women's Mobilization, Institutions, and Gender Outcomes (New York: Oxford University Press).

Zamfir C. and Filipescu I. (eds.), 2015. Romanian Sociology: 1900-2010. A Social History (Sociologia Romaneasca: 1900-2010. O Istorie Sociala) (Cluj-Napoca: Editura Scoala Ardeleana, Eikon).

\section{Chapters in Edited Volumes}

Cheschebec R., 2012. 'The achievement of female suffrage in Romania', in B. Rodríguez-Ruiz and R. Rubio-Marín (eds.), The Struggle for Female Suffrage in Europe: Voting to Become Citizens (Leiden and Boston: Brill), pp. 357-372.

Dobos C., 2010. 'Socio-economic measures to stimulate natality in "Eastern Europe"(Masuri socioeconomice de stimulare a natalitatii in "Europa de Est")', in C. Dobos (ed.)., The Pronatalist Politics of Ceausescu Regime (Politica Pronatalista a Regimului Ceausescu), vol. I (Iasi: Polirom), pp. 189-222.

Duculescu V. and Adam R, 2006. 'Romania', in A. E. Kellermann, J. Czuczai, S. Blockmans, A. Albi, W. Th. Douma (eds.), The Impact of EU Accession on the Legal Orders of New EU Member States and (Pre-)Candidate Countries: Hopes and Fears (The Hague: TMC Asser Press), pp. 113-141.

Fischer M. E., 1985. 'Women in Romanian politics: Elena Ceausescu, pronatalism, and the promotion of women', in S. L. Wolchik and A. G. Meyer (eds.), Women, State, and Party in Eastern Europe (Durham, NC: Duke University Press), pp. 121-137.

1998. 'From tradition and ideology to elections and competition: The changing status of women in Romanian politics', in M. Rueschemeyer (ed.), Women in the Politics of Postcommunist Eastern Europe (Armonk, NY: M. E. Sharpe), pp. 168-195.

Gheorghe C., Mark, L. and Vincze, E., 2018. 'Towards an anti-racist feminism for social justice in Romania', in A. Kóczé, V. Zentai, J. Jovanovic, E. Vincze (eds.), The Romani Women's Movement: Struggles and Debates in Central 
and Eastern Europe, 1st edn (Abingdon, Oxon and New York, Routledge), pp. 111-134.

Goellner R., 2014. 'Die Verfassungsentwicklung in Rumaenien nach 1990', in E. Bos and K. Pocza (eds.), Verfassungsgebung in konsolidierten Demokratien (Baden-Baden: Nomos Verlag), pp. 175-191.

Grunberg L., 2000. 'Women's NGOs in Romania', in S. Gal and G. Kligman (eds.), Reproducing Gender: Politics, Publics, and Everyday Life after Socialism (Princeton University Press), pp. 307-336.

Hein M. and Gherghina S., 2016. 'Romania', in A. Fruhstorfer and M. Hein (eds.), Constitutional Politics in Central and Eastern Europe: From Post-Socialist Transition to the Reform of Political Systems (Wiesbaden: Springer VS), pp. 173-197.

Iancu B., 2015. 'Separation of powers and the rule of law in Romania: The crisis in concepts and contexts', in A. von Bogdandy and P. Sonnevend (eds.), Constitutional Crisis in the European Constitutional Area (Oxford: Hart Publishing), pp. 153-170.

Institutul Revolutiei Romane din Decembrie 1989 (Bucuresti), 2009. Documents Regarding the Romanian Revolution from December 1989. The Activity of the Provisory Council of National Unity (1 February - 11 May 1990) [Documente Privind Revoluția Romana din Decembrie 1989. Activitatea Consiliului Provizoriu de Uniune Nationala (1 februarie - 11 mai 1990)], vol. I (ClujNapoca: MEGA).

Massino J., 2004. 'Women's anonymity in the aesthetics of Ceausescu's Romania (Anonimatul femeii in estetica Romaniei ceausiste)', in A. Ciupala (ed.), About Women and Their History in Romania (Despre Femei si Istoria lor in Romania) (Editura Universitatii din Bucuresti), pp. 137-157.

Miroiu M., 2015. 'On women, feminism and democracy', in L. Stan and D. Vancea (eds.), Post-Communist Romania at Twenty-Five: Linking Past, Present, and Future (Lanham, MD: Lexington Books), pp. 87-105.

Molocea A., 2015. 'Reconstructing Romanian feminism within women's movement (1990-2000) [(Re)Constructia feminismului romanesc in cadrul miscarii de femei (1990-2000)]', in M. Miroiu (ed.), Environmental and Feminist Movements in Romania (1990-2014) [Miscari Feministe si Ecologiste in Romania (1990-2014)] (Iasi: Polirom), pp. 19-87.

Nimu A., 2016. 'Nongovernmental organizations for women's rights: Contextual approaches, personal experiences (Organizatii neguvernamentale pentru drepturile femeilor: Abordari contextuale, experiente personale', in A. Nimu et al. (eds.), Civil Society, Democracy and Institution Building (Societate Civila, Democratie si Constructie Institutionala) (Iasi: Polirom), pp. 103-122.

Olteanu C. L., 2004. 'The cult of Elena Ceausescu in the 1980s (Cultul Elenei Ceausescu in anii '80)', in A. Ciupala (ed.), About Women and Their History 
in Romania (Despre Femei si Istoria lor in Romania) (Editura Universitatii din Bucuresti), pp. 158-179.

Parau C., 2013. 'Romania's transnational constitution: A tradition of elite learning and self-empowerment', in D. Galligan and M. Versteeg (eds.), The Social and Political Foundations of Constitutions (Cambridge University Press), pp. 497-531.

Pavel D., 2014. 'The myth of "the founding father" of the post-communist democracy Corenliu Coposu (Mitul "parintelui fondator" al democratiei postcomuniste Corneliu Coposu', in C. Fulger and T. C. Zarojanu (eds.), The Senior Corneliu Coposu (Seniorul Corneliu Coposu) (Bucuresti: Humanitas), pp. 62-75.

Roth S., 2008. 'Introduction', in S. Roth (ed.), Gender Politics in the Expanding European Union: Mobilization, Inclusion, Exclusion (Oxford: Berghahn Books), pp. 1-16.

Sadurski W., 2001. 'Conclusions: On the relevance of institutions and the centrality of constitutions in post-communist transitions', in J. Zielonka (ed.), Democratic Consolidation in Eastern Europe, vol. 1: Institutional Engineering (Oxford University Press), pp. 455-474.

Stan L., 2014. 'Women as anti-communist dissidents and secret police collaborators', in F. C. Andreescu and M. J. Shapiro (eds.), Genre and the (Post)Communist Woman. Analyzing Transformations of the Central and Eastern European Female Ideal (Abingdon, Oxon and New York: Routledge), pp. 80-97.

Stanescu-Stanciu T., 2011. 'Introductive study. A new Central and South-East Europe and its new political structure: Constitutional corpus. Romania (Studiu introductiv. Noua Europa Centrala si de Sud-Est si noile sale structuri politice. Corpusuri constitutionale. Romania)', in T. Stanescu-Stanciu and F. Neacsu (eds.), The First Constitution of Post-1989 Romania. Documents (Prima Constitutie a Romaniei Postdecembriste. Documente), vol. I (Ploiesti: Karta-Graphic), pp. 13-71.

Vese V., 2001. 'The condition of women in Romania during the communist period', in A. K. Isaacs (ed.), Political Systems and Definitions of Gender Roles (Edizioni Plus - Universita di Pisa), pp. 269-272.

Vlad I., 2015. 'Developments within Romanian women's movement after 2000 (Dezvoltari in miscarea de femei dupa 2000)', in M. Miroiu (ed.), Environmental and Feminist Movements in Romania (1990-2014) [Miscari Feministe si Ecologiste in Romania (1990-2014)] (Iasi: Polirom), pp. 89-187.

\section{Journal Articles}

Andreescu G., 2012. 'The draft law regarding the life-long trauma of women requesting abortion services (Proiectul de lege privind traumatizarea pe viata a femeilor care solicita intreruperea sarcinii)', Noua Revista de Drepturile Omului 8(1), pp. 28-48. 
Ana A., 2017. 'The role of the feminist movement participation during the winter 2012 mobilisations in Romania', Europe-Asia Studies 69(9), pp. 1473-1498.

Borza I., 2010. 'A lacking legitimacy in the transposition of the EU's equal opportunity directives: The case of Romania', Women's Studies International Forum 33(1), pp. 47-53.

Blokker P., 2013. 'Constitution-making in Romania: From reiterative crises to constitutional moment?', Romanian Journal of Comparative Law 3(2), pp. 187-204.

2017. 'The Romanian constitution and civic engagement', Vienna Journal on International Constitutional Law 11(3), pp. 437-455.

Brodeala E., 2017. 'The changing status of women as others in the Romanian constitution', Vienna Journal on International Constitutional Law 11(4), pp. 541-564.

Cormos, G., 2010. 'Romanian women under political repression during the communist era', Scientific Journal of Humanistic Studies 1(3), pp. 18-28.

Cotoi C., 2011. 'Jottings on the history of Romanian sociology', Studia Universitatis Babes-Bolyai-Sociologia 56(1), pp. 135-149.

Dahlerup D. and Gaber M. A., 2017. 'The legitimacy and effectiveness of gender quotas in politics in CE Europe', Teorija in Praksa 54(2), pp. 307-316.

Dima B., 2011. 'The commission for a new constitution - A civil society prospective on the process of constitutional revision', Romanian Journal of Comparative Law 2(1), pp. 151-172.

Gherghina S. and Miscoiu S., 2016. 'Crowd-sourced legislation and politics', Problems of Post-Communism 63(1), pp. 27-36.

Ghodsee K., 2011. 'On feminism, philosophy and politics in post-communist Romania: An interview with Mihaela Miroiu (Bucharest, 17 May 2010)', Women's Studies International Forum 34(4), pp. 302-307.

Harsanyi D. P., 1994. 'Romania's women', Journal of Women's History 5(3), pp. 30-54.

Janova M. and Sineau M., 1992. 'Women's participation in political power in Europe', Women's Studies International Forum 15(1), pp. 115-128.

Kenney P., 1999. 'The gender of resistance in communist Poland', The American Historical Review 104(2), pp. 399-425.

Kligman G., 1990. 'Reclaiming the public: A reflection on creating civil society in Romania', East European Politics and Societies 4(3), pp. 393-438.

Leveel L., 2012. 'Simone de Beauvoir and Romania: A distant gaze (circa 1965-1977)', Colloquia. Journal of Central European History 19, pp. 116-127.

Miroiu M., 2007. 'Communism was a state patriarchy, not state feminism', Aspasia 1(1), pp. 197-201.

2010. 'A mind of our own. Gender studies in Romania', Aspasia 4(1), pp. 157-167. Moskoff W., 1982. 'The problem of the "double burden" in Romania', International Journal of Comparative Sociology 23(1-2), pp. 79-88. 
Perju V., 2015. 'The Romanian double executive and the 2012 constitutional crisis', International Journal of Constitutional Law 13(1), pp. 246-278.

Petrescu C., 2014. 'A genderless protest: Women confronting Romanian communism', Annals of the University of Bucharest 16(2), pp. 79-101.

Popa R. M., 2016. "We opposed it": The National Council of Women and the ban on abortion in Romania', Aspasia 10(1), pp. 152-160.

Rostas R, 2011. 'The second marginalisation of the Bucharest sociological school', ACUM 5(1), pp. 69-80.

Tanasescu S., 2013. 'The revision of the constitution is not a panacea and we should not have too high expectations from a simple modification of legal rules ('Revizuirea constitutiei nu este un panaceu si nu ar trebui sa avem asteptari prea mari de la o simpla modificare de norme juridice)', Pandectele Romane, (12), pp. 15-18.

2014. 'Should the Romanian constitution be revised? (Trebuie revizuita Constitutia Romaniei?)', Dreptul, (5), pp. 11-13.

Wald P. M., 1993. 'Some Unsolicited Advice to My Women Friends in Eastern Europe', SMU Law Review 46(3), pp. 557-583.

\section{Unpublished Material}

Cheschebec R, 2005. 'Feminist Ideologies and Activism in Romania (Approx. 1890s-1940s): Nationalism and Internationalism in Romanian Projects for Women's Emancipation', unpublished PhD thesis, Central European University, Budapest, Hungary, History Department 2005/2

Mihai T., 2016. 'The Political Representation of Romanian Women, in the Context of Europeanization (Reprezentarea Politica a Femeilor din Romania, in Contextul Europenizarii)', unpublished PhD thesis, Scoala Nationala de Studii Administrative si Politice (National School of Administrative and Political Studies), SNSPA, Bucharest, Romania.

Pietraru D. I., 1996. 'The Romanian Constitution of 1991: The 'Stolen' Constitution', unpublished PhD thesis, New School of Social Research, New York, United States of America.

Ronnas P., 1984.'Urbanization in Romania. A Geography of Social and Economic Change Since Independence', unpublished PhD thesis, Stockholm School of Economics.

\section{Newspaper Articles, Blog Posts, Reports, Websites and Other Sources}

2003 Regular Report on Romania's Progress towards Accession, European Commission, 2003, www.ec.europa.eu/neighbourhood-enlargement/sites/near/files/ archives/pdf/key_documents/2003/rr_ro_final_en.pdf. 
'A part of the Romanian civil society denounces the deficient fashion in which the process of constitutional reform has taken place so far $(\mathrm{O}$ parte a societatii civile din Romania reclama modul defectuos in care s-a desfasurat pana in prezent procesul de reforma constitutionala)', Romanian Global News, 2 July 2017 (Document on file with the authors).

Baluta O., 28 May 2016. 'Three millions of boyars (Trei milioane de jupani)', Adevarul.Ro (blog), www.adevarul.ro/news/politica/trei-milioane-jupani-1_ 574952b55ab6550cb8634cea/index.html.

Boghiceanu A., 19 February 2013. 'The constitutional forum will have three axes: Territorial, thematic and academic (Forumul constitutional va avea trei axe: teritoriala, tematica si academica)', Adevarul, www.adevarul.ro/news/poli tica/forumul-constitutional-trei-axe-teritoriala-tematica-academica-1_ 512318e900f5182b8579d06e/index.html.

Bosomitu S., 2 December 2013. 'In the age of "misery". The Romanian sociology during the communist regime (1948-1977) [I]', Cooperativa Gusti, www.cooperativag.ro/age-misery-romanian-sociology-communist-regime1948-1977/.

Brodeală, E., 30 October 2018. 'Human rights should not be subject to a popular vote: Lessons from Romania's failed anti-LGBT referendum', OxHRH (blog), http://ohrh.law.ox.ac.uk/human-rights-should-not-be-subject-to-apopular-vote-lessons-from-romanias-failed-anti-lgbt-referendum/.

Constantinovici C., 4 February 2014. 'PNL MP Florica Chereches reactivates the anti-abortion law proposed by PDL in 2012 (Deputatul PNL Florica Chereches reactiveaza legea anti-avort propusa de PDL in 2012)', Pandoras.Realitatea.Net, www.pandoras.realitatea.net/life/deputatul-pnl-foricachereches-reactiveaza-legea-anti-avort-propusa-de-pdl-in-2012-32375.html.

Constitutional Forum: Final Report (Forum Constitutional: Raport Final), 2003, on file with the authors.

(Forum Constitutional: Raport Final), 2013, on file with the authors.

Costea A., 14 June 2014. 'New president at the Union of Women from BihorMiorita Sateanu retired (Presedinte nou la uniunea femeilor din Bihor Miorita Sateanu s-a Retras din Functie)," Crisana, www.crisana.ro/stiri/ social-9/presedinte-nou-la-uniunea-femeilor-din-bihor-miorita-sateanu-sa-retras-din-functie-15117.html.

15 May 2017. 'Hundreds of students responded to the invitation of the Union of Women from Bihor - They celebrated the Family Day through debates (Sute de elevi au raspuns invitatiei Uniunii Femeilor din Bihor - Au sarbatorit Ziua Familiei prin dezbateri)', Crisana, www.crisana.ro/stiri/eveniment-1/ sute-de-elevi-au-raspuns-invitatiei-uniunii-femeilor-bihor-au-sarbatorit-ziuafamiliei-prin-dezbateri-157538.html.

Communique to the Country of the Front of National Salvation Council, published in the Official Gazette, Part I no.1 of 22 December 1989 (Comunicat catre 
tara al Consiliului Frontului Salvarii Nationale, publicat in Monitorul Oficial, Partea I no. 1 din 22 decembrie 1989).

'Country strategies for the rule of law program for Albania, Bulgaria, Croatia, Czech Republic, Estonia, Hungary, Latvia, Lithuania, Macedonia, Poland, Romania, and Slovakia. Submitted to the U.S. Agency for International Development', American Bar Association, Central and East European Law Initiative (CEELI), 23 August 1993, on file with the authors.

Dogioiu I. E., 12 May 2017. 'Traditional family? Jesus does not say anything on this subject. We care more about customs than people (Familia traditionala? Iisus nu spune nimic pe aceasta tema. Ne sunt mai dragi cutumele decat oamenii)', Ziare.com, www.ziare.com/social/romani/familia-traditionalaiisus-nu-spune-nimic-pe-aceasta-tema-ne-sunt-mai-dragi-cutumele-decatoamenii-interviu-1465223.

Dragan F., 8 July 2017. 'Oana Baluta: $\mathrm{CpF}$ wants to impose a totalitarian vision regarding people's personal choices (Oana Baluta: $\mathrm{CpF}$ vrea sa impuna o viziune totala asupra alegerilor private ale oamenilor)', Romania Libera, www.romanialibera.ro/special/documentare/oana-baluta-cpf-vrea-sa-impunao-viziune-totala-asupra-alegerilor-private-ale-oamenilor-457127.

European Commission for Democracy through Law (Venice Commission), 21-22 March 2014. Opinion on the Draft Law on the Review of the Constitution of Romania.

Feffer J., 31 July 2014. 'Empowering women in Romania', John Feffer (blog), www.johnfeffer.com/empowering-women-in-romania/.

Filip R., 8 June 2017. 'I attended the launching of RESPECT Platform to find out how will they stop the Coalition for Family (Am fost la lansarea platformei RESPECT ca sa aflu cum vor opri Coalitia pentru Familie', Vice, www.vice.com/ro/article/ywzw9w/ce-e-platforma-respect.

Gheorghiu L., 9 February 2015. 'Twenty-five years since the establishing of the first post-communist parliament - CPUN (25 de ani de la infintarea primului parlament postdecembrist - CPUN)', Cotidianul.ro, www.cotidianul.ro/25de-ani-de-la-infiintarea-primului-parlament-postdecembrist-cpun/.

Ghilezan M., 28 September 2009. 'The curse of Elenas (Blestemul Elenelor)', Observator Cultural no. 489, www.observatorcultural.ro/articol/blestemulelenelor.

'Liberty Counsel defends natural marriage in Romania', press release on the Official Website of Liberty Council, 23 November 2016, www.lc.org/newsroom/details/ 112316-liberty-counsel-defends-natural-marriage-in-romania-1.

Lovatt C., 12 July 1999. 'The legacy of Elena Ceaușescu', Central Europe Review 1 (3), www.ce-review.org/99/3/women_lovatt3.html.

Miroiu M. and Baconschi T., 16 May 2017. 'The traditional family in the constitution (Familia traditionala in constitutie)', Revista 22, www.revista22.ro/ 70262750/familia-tradiional-n-constituie.html. 
Official Statement of the Association of Romanian Families (document on file with the authors), www.variantacojocaru.ro/ConstitutiaPoporului/propuneri/pro punere-Alianta-Familiilor-din-Romania.pdf.

Official Website of the Romanian Senate, www.senat.ro.

Open letter: The process of constitutional review must be transparent! (Scrisoare deschisa: Procesul de revizuire a constitutiei trebuie sa fie transparent!), ECPI, 13 March 2013, www.ecpi.ro/scrisoare-deschisa-procesul-de-revizuire-a-constitu tiei-trebuie-sa-fie-transparent/.

Perju V., 30 May 2013. 'The analysis of the Final Report of the Constitutional Forum 2013 (Part I) (Analiza Raportului Final al Forumului Constitutional 2013 (Partea I)), Contributors.ro, www.contributors.ro/dezbatere/analizaraportului-final-al-forumului-constitutional-2013-partea-i/.

Press Release - PSD Bihor (Comunicat de Press - PSD Bihor), AGERPRES, 12 November 2014, www.agerpres.ro/comunicate/2017/11/26/comunicatde-presa-psd-bihor-11-31-03.

Press Release: The March for Life 2017 in Romania: 110,000 [...] participants in 138 cities, The Official Website of the Romanian March for Life, 27 March 2017, www.marsulpentruviata.ro/press-release-march-life-2017-romania110000-de-participants-138-cities.

NATO, 2004. 'Romania - National Report', www.nato.int/ims/2004/win/romania.pdf. Tashman B., 8 September 2015. 'Liberty Counsel invokes communist Romania to denounce "persecution" of Kim Davis', Right Wing Watch, www.rightwingwatch .org/post/liberty-counsel-invokes-communist-romania-to-denounce-persecu tion-of-kim-davis.

'The civil society asks the parliament to respect and protect the diversity of family in Romania (Societatea civila cere parlamentului sa respecte si sa protejeze diversitatea familiei in Romania), Official Website of FRONT Association, 7 November 2016, www.feminism-romania.ro/activism/38-ong/1280societatea-civila-cere-parlamentului-sa-respecte-si-sa-protejeze-diversitateafamiliei-in-romania.

'The evolution of women's representation in the parliament of Romania', Electoral Permanent Authority of Romania, Department of Studies, Documentation and Monitoring of the Electoral Process, 2013, www.roaep.ro/prezentare/ wp-content/uploads/2013/04/women_Parliament.pdf.

'The first meeting of poet Ana Blandiana with Ion Iliescu, in December 1989. 'This is when I understood that people like Doina Cornea and me were there to be put in the window' (Prima intalnire a poetei Ana Blandiana cu Ion Iliescu, in Decembrie 1989. 'Atunci am inteles ca oameni ca Doina Cornea si ca mine erau acolo sa fie pusi in vitrina')', Revolutions, 19 December 2014, www.revolutions.gandul.info/stiri/prima-intalnire-a-poetei-ana-blandianacu-ion-iliescu-in-decembrie-1989-atunci-am-inteles-ca-oameni-ca-doinacornea-si-ca-mine-erau-acolo-sa-fie-pusi-in-vitrina-13732015. 
'The foundation of Romanian prolife movement', on the Official Website of the Pro-Vita Bucuresti Organisation, www.provitabucuresti.ro/english/on-thefoundation-of-romanian-prolife-movement.

'The new constitution: The amendment according to which family is based on the freely-consented marriage between a man and a woman, adopted (Noua constitutie: Amendamentul conform caruia familia se intemeiaza pe casatoria liber consimtita intre un barbat si o femeie, adoptat)', Mediafax, 5 June 2013, www.mediafax.ro/social/noua-constitutie-amendamentulconform-caruia-familia-se-intemeiaza-pe-casatoria-liber-consimtita-intre-unbarbat-si-o-femeie-adoptat-10930830.

The Facebook page of CpF, www.facebook.com/coalitiapentrufamilie/.

The Facebook page of 'Feminism Pro Familie', www.facebook.com/ feminismprofamilie.

The Official Website of ACCEPT NGO, www.acceptromania.ro.

The Official Website of ACTEDO NGO, www.actedo.org.

The Official Website of ADF International, www.adfinternational.org.

The Official Website of ALEG NGO, www.aleg-romania.eu.

The Official Website of AnA NGO, www.anasaf.ro (this Website currently appears to be unclaimed).

The Official Website of Asociatia Front, www.feminism-romania.ro.

The Official Website of Asociatia Mame pentru Mame, www.mamepentrumame.ro. The Official Website of Centrul Filia, www.centrulfilia.ro.

The Official Website of Centrul Parteneriat pentru Egalitate, www.cpe.ro.

The Official Website of ECPI NGO, www.ecpi.ro.

The Official Website of E-Romanja NGO, www.e-romnja.ro.

The Official Website of Liberty Council, www.lc.org.

The Official Website of Peter Costea, www.costea-parlamentuleuropean.ro.

The Official Website of Platforma Respect, www.platformarespect.ro.

The Official Website of the Association 'Parents for religious teaching (Parinti pentru Ora de Religie)', www.oradereligie.ro.

The Official Website of the Coalition for Family (Coalitia pentru Familie), www.coalitiapentrufamilie.ro.

The Official Website of the European Network of Legal Experts in Gender Equality and Non-Discrimination, www.equalitylaw.eu/country/romania.

The Official Website of the Necuvinte NGO, www.necuvinte.ro.

The Official Website of the Pro Democracy Association (Asociatia Pro Democratia, APD), www.apd.ro.

The Official Website of the Romanian Chamber of Deputies, www.cdep.ro.

The Official Website of the Society for Contraceptive and Sexual Education (Societatea de Educatie Contraceptiva si Sexuala), www.secsromania.wordpress.com.

The Official Website of the Women's Association of Romania (Asociatia Femeilor din Romania)', www.afr.ro. 
The Official Website of the Women's Lobby, www.womenlobby.org/RomanianWomen-s-Lobby.

The Transcript of the Council of FSN from 27 December 1989 (Stenograma Sedintei CFSN din 27 Decembrie 1989), on file with the authors.

'The Union of Women from Bihor - Archives (Uniunea Femeilor Din Bihor, Arhiva)', BihorStiri.Ro, www.bihorstiri.ro/tag/uniunea-femeilor-bihor.

'Women and Civil Society - The NGO Guide 2004 (Femeile si Societatea Civila Ghidul Organizatiilor Nonguvernamentale 2004)', Anasaf.ro, www.anasaf .ro/ro/ONG/U-Z/uniunea_femeilor.html.

\section{Legislation, Legislative Proposals and Case Law}

The 1866 Constitution, published in the Official Gazette no. 142 of 1 June 1866 (Constitutia din 1866, publicata in Monitorul Official nr. 142 din 1 iunie 1866).

The 1923 Constitution, published in the Official Gazette no. 282 of 29 March 1923

(Constitutia din 1923, publicata in Monitorul Official nr. 282 din 29 martie 1923).

The 1938 Constitution, published in the Official Gazette no. 48 of 27 February 1938 (Constitutia din 1938, publicata in Monitorul Oficial nr. 48 din 27 februarie 1938).

The 1948 Constitution, published in the Official Gazette no. 87a of 13 April 1948

(Constitutia din 1948, publicata in Monitorul Oficial nr. 87 bis din 13 aprilie 1948).

The 1952 Constitution, published in the Official Bulletin no. 1 of 27 September 1952 (Constitutia din 1952, publicata in Buletinul Oficial nr. 1 din 27 septembrie 1952).

The 1965 Constitution, published in the Official Bulletin no. 1 of 21 August 1965 (Constitutia din 1965, publicata in Buletinul Oficial nr. 1 din 21 august 1965).

The 1991 Constitution, published in the Official Gazette no. 233 of 21 November 1991, republished with amendments in the Official Gazette no. 767 of 31 October 2003 (Constitutia din 1991, publicata in Monitorul Oficial nr. 233 din 21 noiembrie 1991, republicata cu modificari in Monitorul Oficial nr. 767 din 31 octombrie 2003).

Decree $1 / 1989$ on the abrogation of some laws, decrees and other normative acts, published in the Official Gazette no. 4 of 27 December 1989 (Decretul 1/ 1989 privind abrogarea unor legi, decrete şi alte acte normative, publicat in Monitorul Oficial nr. 4 din 27 decembrie 1989).

Decree 2/1989 on the establishment, organisation and functioning of the Council of the National Salvation Front and of the Territorial Councils of the National Salvation Front, published in the Official Gazette no. 4 of 
27 December 1989 (Decretul 2/1989 privind constituirea, organizarea şi functionarea Consiliului Frontului Salvarii Nationale şi a consiliilor teritoriale ale Frontului Salvarii Nationale, publicat in Monitorul Oficial nr. 4 din 27 decembrie 1989).

Decree $31 / 1990$ on paid leave for the care of children aged up to one year, published in the Official Gazette no. 12 of 19 January 1990 (Decretul 31/ 1990 privind concediul platit pentru ingrijirea copiilor in varsta de pana la un an, publicat in Monitorul Oficial nr. 12 din 19 ianuarie 1990).

Decree $51 / 1990$ on the seniority in the workplace of the working wife who is accompanying her husband sent in a permanent mission abroad, published in the Official Gazette no. 20 of 6 February 1990 (Decree 51/1990 privind vechimea in munca a sotiei salariate care isi urmeaza sotul trimis in misiune permanenta in strainatate, publicat in Monitorul Oficial nr. 20 din 6 februarie 1990).

Decree $60 / 1990$ on the retirement with age reduction of some employees, published in the Official Gazette no. 21 of 8 February 1990 (Decree 60/1990 privind pensionarea cu reducere de varsta a unor salariati, publicat in Monitorul Oficial nr. 21 din 8 februarie 1990).

Decree 81/1990 on the Provisional Council of National Union, published in the Official Gazette no. 27 of 10 February 1990 (Decretul 81/1990 privind Consiliul Provizoriu de Uniune Nationala, publicat in Monitorul Oficial nr. 27 din 10 februarie 1990).

Decree 92/1990 on the election of the Parliament and of the President of Romania, published in the Official Gazette no. 35 of 18 March 1990 (Decretul 92/1990 pentru alegerea Parlamentului şi a Presedintelui Romaniei, publicat in Monitorul Oficial nr. 35 din 18 martie 1990).

Law 167/1929 regarding the Organisation of Local Administration, published in the Official Gazette no. 170 of 3 August 1929 (Legea 167/1929 pentru organizarea administratiunii locale, publicata in Monitorul Oficial nr. 170 din 3 august 1929).

Law 47/1992 on the Organisation and Functioning of the Constitutional Court, republished in the Official Gazette, Part I, no. 807 of 3 December 2010 (Legea 47/1992 privind organizarea si functionarea Curtii Constitutionale, republicata in Monitorul Oficial, Partea I, nr. 807 din 3 decembrie 2010).

Law $189 / 1999$ on the exercise of the legislative initiative by citizens, published in the Official Gazette no. 611 of 14 December 1999 (Legea 189/1999 privind exercitarea initiativei legislative de catre cetateni, publicata in Monitorul Oficial nr. 611 din 14 decembrie 1999).

Law 429/2003 regarding the revision of the Romanian Constitution, published in the Official Gazette no. 669 of 22 September 2003 (Legea 429/2003 de revizuire a Constitutiei Romaniei, publicata in Monitorul Oficial nr. 669 din 22 septembrie 2003). 
Decision $80 / 2014$ of the Constitutional Court of Romania on the legislative proposal on the revision of the Romanian Constitution, published in the Official Gazette, Part I, no. 246 of 7 April 2014 (Decizia 80/2014 a Curtii Constitutionale a Romaniei asupra propunerii legislative privind revizuirea Constitutiei Romaniei, publicata in Monitorul Oficial, Partea I, nr. 246 din 7 April 2014).

Decision 580/2016 of the Constitutional Court of Romania on the Citizens' Legislative Initiative entitled 'Law on the Revision of the Romanian Constitution', published in the Official Gazette no. 857 of 27 October 2016 (Decizia $580 / 2016$ asupra initiativei legislative a cetatenilor intitulata „Lege de revizuire a Constitutiei Romaniei”, publicata in Monitorul Oficial nr. 857 din 27 octombrie 2016).

Decision 539/2018 of the Constitutional Court of Romania on the constitutionality of the law to review the Romanian Costitution, published in the Official Gazette no. 798 of 27 September 2016 (Decizia 539/2018 asupra constitutionalitatii Legii de revizuire a Constitutiei Romaniei, publicata in Monitorul Oficial nr. 798 din 18 septembrie 2018).

Legislative Proposal for the Revision of the Romanian Constitution, L233/2014 (Propunere Legislativa de Revizuire a Constitutiei Romaniei, L233/2014), 7 February 2014, on the Official Website of the Romanian Senate www.senat.ro/legis/PDF/2014/14L233FG.pdf.

${ }^{*}$ All links were accessed and functioning on 15 July 2018, unless otherwise stated. 